\title{
Kniplingskræmmer Jens Wulffs dagbog
}

Uddrag ved Peter Kr. Iversen.

Indledning.

„... Gid ingen smertelige begivenheder være disse blade forbeholdt, gid ingen tab af elskte kiere vorde optagen i samme, gid samme ei maatte fortælle uhældige tildragelser for mig eller mine paarørende og venner, ingen slet og nedrig og uværdig handling af samme, men for alt ingen forsætlig slet og nedrig og udydig handling af mig selv. - Gid ieg altiid roelig og med god bevidsthed maatte kunde tage min dagebog til hande og med roelighed og glæde see hen til hver hensvunden dag. - $\mathrm{O}$ ! da vil ieg glæde mig til disse blade, naar ieg i seenere tiid tager dem til haande igien og med fornøyelse igien hensætte mig til den hensvundne tiid ......"

Således indleder kniplingskræmmer Jens Wulff fra Brede det dagbogsbind, han påbegynder 1 . marts 1815 , og disse ord kan meget vel stå som en slags ledetråd for hans virksomhed som dagbogsskribent.

Han har allerede i sin tidligste ungdom som vandrende kniplingskræmmer i de nordtyske lande været nødt til at føre en slags journal og regnskabsibog over sine handler, men 1804 er han gået over til at føre en egentlig dagbog, og dag for dag har han derefter i over 50 år berettet om sine oplevelser, tanker og følelser. Ialt er der fra tiden $1804-58$ bevaret 15 bind, nemlig fra årene $1804-06,1809-10,1813-26,1828-31$ og 1836-58. Bindet 1815-18 opbevares på museet i Tønder, medens alle de ovrige beror på landsarkivet i Åbenrå. Med undtagelse af et par 
af de ældste er bindene alle i oktav format, en del med Jens Wulffs monogram i guld på bindets forside.

Gennem dagbøgerne er det altså muligt at følge Wulff fra 30-årsalderen til nogle dage før hans ded. Og takket være sønnen Hochberg endda et stykke længere, idet sønnen efter faderens død fortsætter dagbogen og giver en udførlig skildring af begravelsen. Endvidere har Hochberg Wulff i det sidste dagbogsbind indført faderens selvbiografi, udarbejdet og indsendt til ordenskapitlet $1854 \mathrm{i}$ anledning af hans udnævnelse til ridder, og der gives heri, navnlig fra Wulffs yngre år, nogle supplerende oplysninger til dagbogsoptegnelserne.

De første dagbogsnotater er kortfattede og meddeler stort set kun oplysninger fra Wulffs færden som kniplingshandler i Tyskland. Kun hist og her er der i de ældste dagbøger optegnelser, der kan siges at have mere almindelig interesse. Med undtagelse af beretningerne om kosakkernes ophold i Vestslesvig og kosakvinteren 1814 er disse spredte optegnelser ikke medtagne i de egentlige dagbogsuddrag, som først tager sin begyndelse med bindet 1836-39, men er indflettet $i$ den indledende levnedsskildring af Jens Wulff.

De enkelte dagbogsoptegnelser indledes med meteorologiske oplysninger, i de ældste bind lidt usystematiske, i de yngste bind mere udførlige og præcise. Ellers berettes der i optegnelserne om stort og småt, om Wulffs virksomhed som kniplingsog uldhandler, om glædelige og sørgelige begivenheder i familie- og vennekredsen, om nationale, politiske og religiøse forhold, og dagbøgerne bliver derved ikke blot kilden til levnedsskildringen og karakteristikken af personligheden Jens Wulff, men leverer også værdifuldt materiale til belysningen af forholdene i Vestslesvig i 1. halvdel af 19. århundrede, især m. h. t. begivenhederne under Treårskrigen. Efterhånden som Wulff bliver mere øvet som dagbogsskribent, afslutter han hver máned med en oversigt over dens vigtigste hændelser, og den 31 . december giver han hvert år en til tider ret udførlig oversigt 
over det svundne år. Disse oversigter er ofte $\mathrm{i}$ dagbogsuddrage$n \in$ gengivet meget fyldige. Foran og bag i dagbøgerne er der indført regnskabsoptegnelser af forskellig art, og det er interessant at bemærke, at disse er skrevne på tysk. De mange rejser 1 Tyskland og Wulffs lange ophold i Altona i de unge år medførte, at han talte lige så godt tysk som dansk, og dette forhold har heller ikke undgået at præge sproget i dagbøgerne. Der er adskillige germanismer, som både mærkes med hensyn til ordvalg, ordstilling og sætningsbygningen i det hele taget. Ofte møder man dog ogsaa gode sønderjyske udtryk.

Da der som nævnt $i$ indledningen vil blive bragt nogle spredte uddrag af dagbøgerne fra tiden før 1836, skal der allerede her ganske kort gøres rede for de retningslinier, der har været lagt til grund for transskriptionen. Uddragene er så vidt muligt gengivet bogstavret, rene skrivefejl er dog rettede, og Wulffs lidt tilfældige anvendelse af små og store begyndelsesbogstaver er normaliseret derhen, at der kun anvendes stort begyndelsesbogstav efter punktum og i egennavne. Har det været nodvendigt for meningen at indsætte ord, er disse omgivet af skarp parentes [ ]. Hvor intet andet er bemærket, er optegnelserne nedskrevne i Brede.

Selv om Wulff kæler for sin kære dagbog, er skriften dog ikke altid lige let læselig, ofte er den udflydende og til tider, især i de første bind, så gnidret, at lup nu og da må tages til hjælp ved læsningen.

Jens Andreas Wulff, som hans fulde navn er, er fadt i Brede d. 1. maj 1774, hvor forældrene Andreas Hansen Wulff (17371814) og Johanne Jensdatter, kaldet Dyrhus, (ca. 1740-1810) drev en lille høkerhandel, der senere blev overtaget af J. Wulffs svoger Niels Mikkelsen (Wulff). I sin dagbog giver J. Wulff faderen 1814 det eftermæle, at han var en klog og belæst mand, som i sine yngre år havde vist megen virksomhed; men han 
havde ført en lidt omtumlet tilværelse. Havde han haft mere selvtillid og „ey agtet sig selv saa ringe“ var han sikkert nået længere $\mathrm{i}$ verden. Han havde måttet kæmpe med okonomisk modgang, men sammen med sin hustru havde han dog magtet at give de 7 børn, der voksede op i hjemmet, en god opdragelse. Eørnene blev vænnet til sparsommelighed og flid, og da de nåede skelsår og alder, blev de efter evne hjulpet godt $\mathbf{i}$ gang.*) Jens Wulffs søskende og deres børn omtales ofte $\mathbf{i}$ dagbogsuddragene, og for at mindske noteapparatet mest muligt vil de derfor ganske kort blive nævnt her i skematisk form. ${ }^{1}$ )

I. Den ældste broder var stænderdeputeret, justitsråd Hans Andreas W. (1764-1850). I sit ægteskab med Caroline Christiane Poulsen (1773-1836) havde han følgende børn: 1) Andreas Anton W. (1795-1856), gårdejer i Bølling, Egtved sogn, senere i Hjortlund; 2) Johanne Henrikke W. (1799-1831), gift med møller Andreas Petersen, Spangsbjerg mølle; 3) Karen Augusta W. (1801-1880), gift med landinspektør, kammerråd Poul Winther Johansen, Neksø, senere Århus; 4) Charlotte Dorthea W. (1806-94), gift med Caspar Alvild Nicolai Georg Toft, Guldager mølle; 5) Carl Vilhelm W. (1811-80), missionær og

*) Herremanden pá Trøjborg, Bendix Holst, synes at have understøttet W's forældre og hjulpet dem med at finde passende lærepladser til børnene. Herom skriver J. W. i sin nekrolog over Bendix Holst 27/2 1829 flg.:

... Var i Wisbye og paa Trøyborg, hvor cancellieraad Holdt døde i det øyeblik, ieg kom til gaarden. Denne mand bliir af mange lastet og ikke ufortient, dog havde han ogsaa sine mange gode siider, var en saare gavnlig mand for denne egn, en mønster paa oeconomisk fliid, orden og betænksomhed, var en fiende af de lade, yndede de flittige, var derved saare hærskesyg og regierede næsten som en fyrste paa sit gods i mange aar. Mine forældre og efter dem deres børm fandt i ham alletiider en velynder, han har mod vores familie alletiider viist sig hielpevillig, og han var et middel til, at vi kom hver paa sin hældige bane af os søskende. - Derfor tak hviile ved hans tænkeminde og fred være med hans aske.

1) Ang. slægten se: A. Noack: Stamtavle over familien Wulff, 1941. 
præst; 6) Hansine Jacobine Henriette W. (1814-1893), gift med Christian Georg Campen, forpagter, senere ejer af Nebel mø!le; 7) Maria Eulalia W. (1819-97), død ugift; endvidere døde et par born som små.

Jens Wulffs øvrige søskende var:

II. Kirstine W. (1768-1839), gift med kniplingskræmmer Iver Asmussen i Bredebro.

III. Gyde Marie W. (1777-1857), gift med købmand Niels Mikkelsen (Wulff); i dette ægteskab var der en søn Johan Andreas Lauritzen Wulff (1819-82).

IV. Johannes Andreas W. (1780-1856), konsistorialråd og præst i Ris. I ægteskabet med Joachimine Friederiche Strodtmann, datter af provst Strodtmann i Haderslev, havde han følgende børn: 1) Adolph Heinrich Strodtmann W. (1816-96); 2) Johanne Jensine Wilhelmine Margrethe W. (1817-96), 3) Andreas Eduard August W. (1819—92), præst i Gettorf, senere i Branderup; 4) Hans Christian Carl W. (1822-97), købmand i Brede; 5) Sophie Amalie W. (1823-1906), gift med Jens Wulffs søn Theodor; 6) Jacob Georg Christian W. (1827-1908), præst i Gråsten og Vodder; 7) en dreng, død som lille.

V. Nicolai W. (1782-1871), garver i Herslev.

VI. Margrethe W. (1786-1863), ugift i Brede, Jens Wulffs medhjælper ved indkøb af kniplinger.

Af Jens Wulffs søskende var den ældste broder Hans W. vel nok den, der drev det længst, idet han blev et fremtrædende medlem af den viborgske stænderforsamling, hvor han bl. a. arbejdede for at skabe en nærmere forbindelse mellem rigets forskellige dele, især onskede han toldgrænsen ved Kongeåen slettet. Også Hans W. havde i sin tidligste ungdom forsogt sig som vandrende kniplingskræmmer, men han opgav denne profession for at blive huslærer hos kammerassessor Lautrup på Estrup i Malt sogn. Senere blev han ridefoged på Estrup (1788 -94) og overtog derefter Nebel mølle i nærheden af Kolding, hvor han gennemførte store kultiveringsarbejder med økon 
misk støtte fra Jens W. Der herskede som regel et godt forhold mellem disse to højt begavede brødre. Kun når økonomiske forhold spillede ind, kunde der for en kortere tid blive kold luft imellem dem, men indtil Hans W.s død 6. januar 1850 korresponderede de dog bestandig sammen, ligesom de også med mellemrum besøgte hinanden eller tog på rejse sammen. Adskillige af de sager, som Hans W. fremdrog i den jyske stænderforsamling, er forinden indgående blevet drøftet med Jens W., som i flere tilfælde endog må siges at være den egentlige ophavsmand til forslagene. ${ }^{2}$ )

Den yngre broder Johannes Andreas W. var derimod som regel ikke nogen velset gæst i Brede. Han var en stejl og stridbar natur, som havde vanskeligt ved at omgås andre, og forholdet mellem ham og broderen Jens blev efterhånden alt andet end broderligt. Allerede $i$ en dagbogsnotits 30/7 $1815 i$ anledning af Johannes Andreas' bryllup med provst Strodtmanns datter Joachimine Friederiche dukker nogle lidt syrlige bemærkninger om broderen frem. Det hedder her: „... Tog med Joh. Andr. og Lauterup ${ }^{3}$ ) til Hadersleff, hvor ieg fandt broder Hans. - Joh. Andr. holdt prækenen; derefter blev han af sin svigerfader, provst Strodtmann, i superintendentens sted, assisteret af 8 nabopræster ordineret og siden kopuleret. Provsten giorde sine ting meget brav, og kopulationen var især rørende, saa faae øyne bleve tørre. - Handlingen varede fra $\mathrm{kl}$. 9 til halvet, bordsælskabet bestod af 24 persohner; i $3^{1 / 2}$ time blev der spist, 12 rætter mad foresatt - og mange henter sig vist en fordervet mave. Sælskabet begyndte derpaa at bryde op, og stadsen var endnu for aften forbi, og ieg med broder Hans kiorte ned til Torning mølle. Himlen give, at denne dag stedse maatte være og blive en gladere dag for min broder og hans bliide

2) Ang. Hans Wulff, se: Fra Ribe Amt, 1908. s. 119-164, og Vejle Amts Aarbфger 1925, s. 197-221.

3) Johann Christian Lautrup, præst i Brede 1797-1845. 
piige, gid han maatte overgive sig selv - sine luner og heftighed - og giøre hende saa lykkelig, som hands ønske er, og som hun vist fortiener. Gid han maatte bruge sin aand og forstand til at virke og gavne sine medmennisker og med ære opfylde den plads, han nu betiener - da vil ieg med glæde og inderlig tilfredshed see hen til ham og ansee de midler, ieg anvendte paa hans studering for de bedst anbragde af alle. - Da vil tanken, at ieg har bragd ham paa den grad af lykke og virksomhed stedse være mig kier og dyrebar overalt.“

Angående den videre udvikling af forholdet mellem Jens og Joh. Andr. Wulff henvises til dagbogsuddragene. ${ }^{4}$ )

I sin selvbiografi skriver Jens Wulff, at de økonomiske forhold i det lille hokerhjem i Brede var "temmelig trængende“. Nogen egentlig uddannelse blev der ikke råd til for børnene, som så snart de havde forladt landsbyskolen måtte ud for at tjene til livets ophold. ${ }^{5}$ ) Jens Wulff kom derfor i sit 14. år til Jylland som skriverdreng hos kammerråd Bolvig på Nebbegård i nærheden af Vejle. Her blev han konfirmeret og kom kort efter i landmålerlære hos landmåler Ravn i Vejle, hvor han dog kun forblev i tre år, da forældrene under et af hans besøg i Brede overtalte ham til at forsøge kniplingshandelen, bl. a. for at kunne give dem en håndsrækning i deres svigtende økonomiske forhold. I sin selvbiografi skriver han, at det var ugerne, han føjede dem deri. Og det blev heller ikke nogen let opgave for den nu 18-årige Jens Wulff at komme i gang med kniplingshandelen. Han havde ingen koncession til at handle herhjemme, og han måtte derfor søge til udlandet, hvor en sådan ikke var nødvendig. Med et ubetydeligt forråd af kniplinger — købt på lykke og fromme, skriver han - tog han med skib fra Rømø til Altona. Da vinden imidlertid var ugunstig, nåede han først her-

4) Ang. pastor J. A. Wulff, se iøvrigt Sønderj. månedsskr. 1947, s.65 ff. 
til efter en sejlads på ikke mindre end fire uger. Han forsøgte forgæves at sælge sine kniplinger her og i Hamburg, og skuffet og noget nedtrykt tog han derfor "fod i haand" og posen på ryggen og vandrede til Lauenburg og Mecklenburg. Først 6 uger efter afrejsen hjemmefra lykkedes det ham her at sælge nogle få alen kniplinger. Stort mere fik han foreløbig ikke solgt, og den unge kræmmer var ved at fortvivle. Han fortjente ikke så meget, som han fortærede, og han mistede snart troen og håbet på, at der var penge at tjene ved den håndtering, han var slået ind på. Som gammel mand skriver han i sin dagbog (9/4 1852), at han ved tanken om forældrenes dårlige kår og de små "uopdragne" søskende gik mange mil grædende, og det var egentlig kun tanken om familien derhjemme, der fik ham til at fortsætte. Da han mange uger havde vandret således omkring og døjet megen nød, mødte han imidlertid en gudfrygtig, fattig tigger, som vækkede det faldne mod i ham. Tiggeren indgød ham lyst og mod til at fortsætte, og som gammel mand mindes han medet med tiggeren i følgende ord: „Ja, velsignet være denne betlers minde, stedse paatænker ieg ham med taknemmelighed, ligesom min tak stiger til Gud, der ved ringe ting veed at fremme menneskets lykke og velvære".

Jens Wulff fortsatte altså sin handelsrejse, han forskrev bedre og mere gangbare varer hjemmefra og begyndte efterhånden at kunne tjene til livets ophold. $\mathrm{Da}$ han havde vandret i fem fjerding år, havde han endda tjent et lille overskud, som han anvendte til at købe sig et lommeur for. Han fik erfarmger, som udnyttes på de følgende rejser, og han tjente efterhånden ganske godt. Han fik råd til at holde hest, og hars afsætningsområde voksede dermed betydeligt; han nåede til Hannover, Pommern, Preussen, Braunschweig, Hessen og Oldenburg. Under sin færd blev han klar over, at han i de sachsiske

5) De yngre søskende kom dog til at nyde godt af nogen privatundervisning hos pastor Lautrup. Joh. Andr. Wulff blev således forberedt af ham til optagelse på latinskolen i Husum. 
kniplinger havde en alvorlig konkurrent; han tog derfor resolut derned for at sætte sig ind i kniplingsfremstillingen her, og - som han skriver - „lærte her adskilligt at kende, som hos os var ubekiendt, hvilket siden blev behørig afbenyttet, hvorved denne industri forbedredes og giorde fremskridt."

I disse første læreår var han også modnedes som menneske. Ved sin 30-års fødselsdag 1804 gør han en slags status over, hvad han hidtil har nået. Lignende tanker moder man ofte senere $i$ hans dagbog, her (1804) er de vidnesbyrd om, at han allerede da er nået frem til et afbalanceret livssyn. Han skriver: „... Saa ere de da svundne de glade, blide ynglinges aar; sandelig det var herlige dage, vist de blideste af mit liv; endogsaa som olding vil tanken og erindringen af disse 10 aar være mig dyrebar. I dem blev grundvold lagt til mit moralske forhold og til min økonomiske forfatning. I dem svandt mange taager fra forstandens øyne, der blænder de fleste mennesker for hele deres livstid og en tid saa meget forstyrrede mit sinds roe".

Under Napoleonskrigene måtte han tage mangen hård $\mathrm{c}_{3}$ farlig tørn. Snart stødte han på franske, snart på engelske, tyske og russiske tropper; liv og gods var ofte $i$ fare. Med nogen stolthed kan han derfor siden berette, at han var den eneste kniplingskræmmer, der tildristede sig at berejse de tyske lande i krigens tid. Og dog fik han ikke nogen økonomisk gevinst herved. Da han kom hjem 1813 efter mange besværligheder fra en handelsrejse, havde han sat ca. $1000 \mathrm{mk}$. cour. til, men når han alligevel gennemførte sine handelsrejser i disse ufredsår, er en væsentlig årsag hertil - det siger han i hvert fald selv hensynet til de mange kniplingspiger, som han efterhånden havde fået $i$ arbejde. Andre kniplingskræmmere afskedigede derimod deres piger og gjorde dem derved brødløse. Der kom også bedre tider igen. Allerede 1814 opnåede han en betydelig gevinst. Dette år blev hans hidtil bedste år som kniplingskræm mer, og han kan d. $31 / 12$ notere i dagbogen, at han dette år har solgt for $50.000 \mathrm{mk}$. cour.; hans nettofortjeneste var $7000 \mathrm{mk}$. 
cour., til trods for at hans udgifter var steget med over 1000 rdlr. Kort tid efter ( $1 / 3$ 1815) oplyser han, at han har en ikke ubetydelig formue, som med lethed årligt kunde forøges, hvis ikke han blev ramt af uheld.

I de tyske lande var en så stor del af hans kunder jediske købmænd, at han i sine rejseplaner blev nødt til at tage hensyn til deres særlige festdage. I et notat 25/9 1815 hedder det således: „... Giort den meget ubehagelige opdagelse, at jødernes nye aar etc. falder ind i min tour og giør min haele reiseplan til intet. - At deres festdage ei falde nogle dage sildigere vil og kand forvolde, at ieg maae giøre en reise af mer end 100 mill, da ieg nu ey naar at faae Preussen med .... "Men selv om han blandt jøderne fandt nogle af sine bedste kunder, må han dog adskillige gange $\mathrm{i}$ sin dagbog give udtryk for sin utilfredshed med deres forretningspraksis.

Efterhånden udstrakte Jens Wulffs handel sig også til de øvrige verdensdele. Han sendte provekollektioner til Syd- og Nordamerika, til Asien, Afrika og Australien. Vel var dette, skriver han i selvbiografien, forbunden med risiko, og han led også tab, men forsøgene blev gjort i det små. Hvor han så fandt gunstige afsætningsmuligheder, fulgte større forsendelser efter, især fandt han et godt marked i Mexico. Hans kniplingehandel udvidede sig efterhånden derhen, at han kunde holde over 1000 kniplepiger i arbejde i de vestslesvigske sogne.

Hans omfattende handel førte med sig, at han næsten altid var på rejse, men efterhånden som han nåede op i årene, begyndte han at trættes ved dette idelige rejseliv, og 1819 overlod han derfor en del af kniplingehandelen til en medhjælper, Georg Hansen fra Tønder, som han dog ikke fik de allerbedste erfaringer med. Ved at antage en medhjælper havde han håbet at få mere tid til at beskæftige sig med "sine landlige ting“, d. v. s. sit landbrug, som han udvidede ved tilkøb af jord og forbeJrede ved overrislingsanlæg og indførelse af nye afgrøder. 
Efter de foreliggende oplysninger var Jens Wulff således den første, der dyrkede roer i Vestslesvig.

Fra slutningen af 1820 'erne begyndte kniplingehandelen at gå tilbage. $\left.{ }^{5}\right)$ Dels kunde de håndkniplede varer ikke i prismæssig henseende konkurrere med de fabriksfremstillede og dels ændrede moden sig. 1829 var for Jens Wulff et dårligt år; han havde underskud på kniplingshandelen og måtte fra Tyskland skrive hjem til søsteren Grethe, at hun skulde indskrænke købet af kniplinger mest muligt. 1830 kan under 21/12 læses følgende i dagbogen: „.... Vare i dag i Scherbeck, hvor vi allene havde 31 stk. ord. knipl., der beløbe sig til $91 \mathrm{mk}$. — En stoer forandring imod forrige tiider, og det lonner sig ikke meere at reise derhen, før tiiden bliver anderledes, og mand kand give piigerne meere for deres arbeide. - Fremmede indfinder sig kuns heel faae at foreviise deres vare - og der bliir saare faae kniplinger giordt denne tiid." Forinden Wulff for alvor begyndte at mærke tilbagegangen $i$ kniplingehandelen, havde han dog taget nye handelsgrene op, hvilket han var $i$ stand til takket være den efterhånden ikke ubetydelige kapital, han havde samlet sig. I 1820'erne havde han handlet lidt med kaffe, og 1829 begyndte han at opkøbe uld til eksport til Tyskland. senere også til Holland, England og Frankrig; særlig til sidstnævnte land blev hans uldeksport efterhånden betydelig. Som det vil ses af dagbogsuddragene fik han dog $i$ denne handel slemme konkurrenter $\mathrm{i}$ franske opkabere og hamburg-altonaiske købmænd. Også jysk bindetøj blev for ham en stor artikel. For denne vare fandt han især afsætning i Nordamerika, og som medhjælper i denne handelsgren havde han sin plejesøn Wilhelm Nissen, der bosatte sig i Husum. Også sønnerne tog han tidligt ind i forretningen. I begyndelsen af 1830'erne havde Hochberg tildels overtaget kniplingshandelen, og 1839 kom også Ferdinand med i kompagniskabet. Sammen med søn-

6) Jvnfr. Sønderjydske årb $ф$ ger 1928, s. 1 ff. 
nerne oprettede han en fabrik til vavning af uld-og bomuldsstoffer i Brede, hvorimod en planlagt sukkerfabrik måt.e opgives. På sine ældre dage handlede han også med raps og korn, men om alle disse forhold vil der senere blive fortalt udforligere i dagbogsuddragene.

Indtil Jens Wulff 30/8 1809 ægtede Auguste Wilhelmine Philippine Henriette Trenckner (1790-1870), der stammede fra St. Andreasburg i Harzen, og hvem han havde lært at kende på sine rejser, havde han Altona til hovedopholdssted. Han havde endda fået borgerskab her. Men efter sit giftermål blev det Brede, der blev hans egentlige hjem og tilflugtssted, når han ikke var på farten. Det hjem, han stiftede her sammen med sin elskede hustru blev såre lykkeligt. I ægteskabet voksede fire børn op, nemlig: 1) Hochberg Wulff, født i Brede 13/9 1811, død sammesteds 30/7 1887; 2) August Ferdinand W., født 12/11 1815, død 3/10 1897, gift 27/9 1855 med Severine Erika Jansen fra Kejtum på Sild; 3) Johanna Maria Theodora W., født 17/9 1822, død 31/3 1872 i Kiel, gift 21/6 1845 med apoteker i Højer Herman Peter Eduard Nagel, født 3/6 1816 i København, død 7/12 1890 i Højer; 4) Carl Vilhelm Theodor W., født 26/8 1825, død 18/2 1899, gift 4/1 1857 med sin kusine Sophie Amalie Wulff, datter af konsistorialråd Joh. Andr. W. En lille dreng, Theodor, var død som 5-årig af „ondartet halsbrynde“, vel difteritis. Desuden var der fra 1814 en plejesøn, den tidligere nævnte Wilhelm Nissen, søn af Carsten Nissen i Altona, og nu og da opholdt også nogle nevøer sig kortere eller længere tid i det Wulff'ske hjem i Brede.

Det var under ret beskedne ydre rammer, J. Wulff 1809 havde sat bo i Brede. Derfor såsnart han havde konsolideret sig nogenlunde i okonomisk henseende, udvidede han sit hus. 1816 tilbyggede han to fag og udførte mange forbedringer på den gamle bygning. Ialt byggede og reparerede han dette år for 


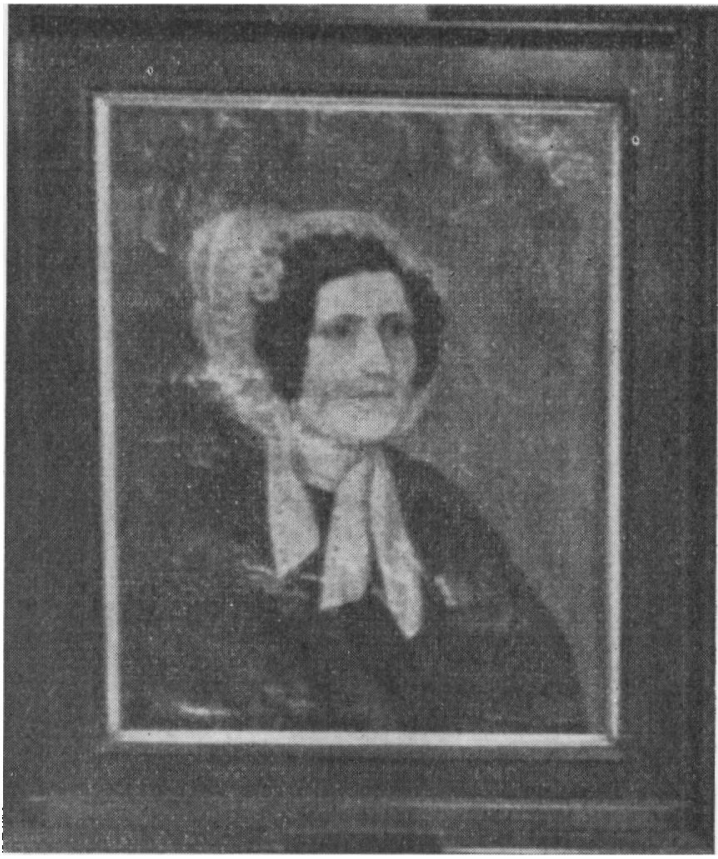

Withelmine Wulff

Maleri, formentlig fra $1830^{\prime} \mathrm{eme}$

$2730 \mathrm{mk}$., en efter datidens forhold betydelig sum, og vandt derved, som han selv skriver $31 / 121816$, "stoer bequemmelighed, og vi have nu det beste og bequemmeste huus, mand vil ønske sig." Fem år senere, 1821, bygger han 10 fag stald og lade, som kostede $1262 \mathrm{mk}$., og efterhånden som børnene voksede til og selskabeligheden tiltog, blev også det udvidede stuehus for lille. I årene 1836 -39 byggede han derfor faktisk hele sin ejendom op fra ny af. Stuehuset, som brændte for nogle år siden, blev rejst 1836, og 1838 blev stald- og ladebygningerne grundig istandsat og til dels nyopførte. Hans byggeudgifter i årene 1836 -39 androg ialt $9420 \mathrm{mk}$. cour., men han havde da også opnået at få et af de smukkeste hjem i Vestslesvig.

De ydre rammer var altså i orden, men Wulff og hans kone forstod også at udfylde dem. Det hjemliv, der kom til at udfolde 


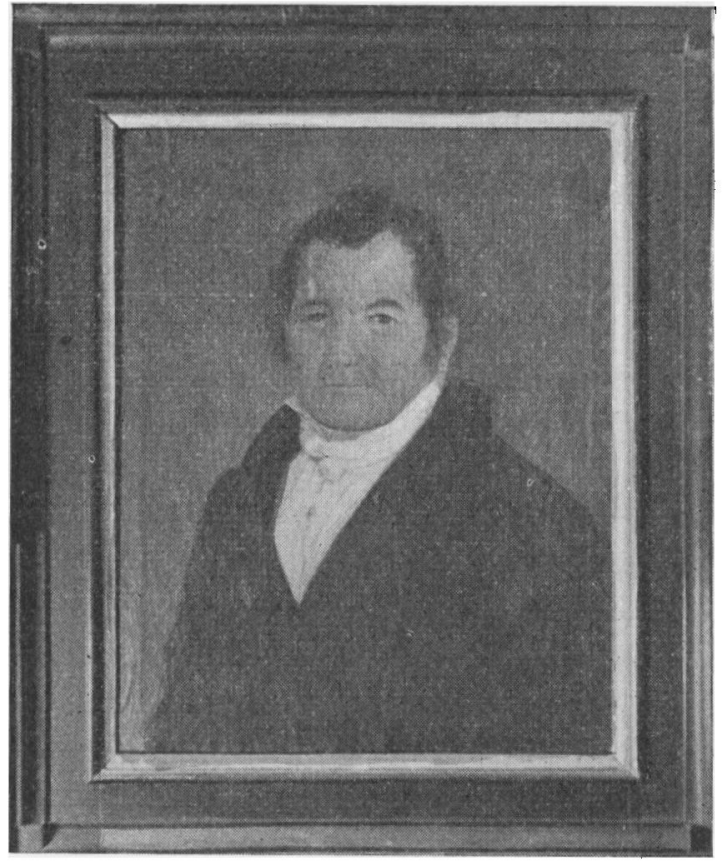

Jens Wulff

Maleri, formentig fra 1830 'erne

sig her, blev mønstergyldigt. Børnene havde ligesom faderen kunstneriske anlæg og interesser, og fritiden blev derfor tilbragt med oplæsning, sang og musik, ofte i selskab med gode venner med lignende interesser. Jens Wulf havde $i$ sine unge år selv skrevet små fortællinger og digte, men vel at mærke på tysk.') Så længe havde han opholdt sig i Tyskland, og så indlevet var han blevet i tysk åndsliv og kultur, at man kan sige, at han hovedsagelig har fået sin åndelige dannelse på tysk. Navnlig under de lange ophold i Altona lærte Wulff meget. Medens hans jævnaldrende søgte forlystelser og andre adspredelser, fjernede han sig fra alt „og levede eenlig for sig selv, levede [for] min

7) Et af hans digte: Die Bezauberung auf dem Blocksberg er trykt i Axel Noack: Stamtavle over Familien Wulff, 1941, s. VI-IX. 
aands og min moralske dannelse, levede for den kommende tiid; her svandt mangen taage for forstandens øye, her blev mig saa meget klar, der før var mørk og skrækkende for mig, her søgede ieg at vorde from og god" (1821 12/5). De fleste af hans små digteriske arbejder er også blevet til her. I disse læreår blev han vel bevandret i tysk litteratur og skuespilkunst, og han havde her modtaget indtryk for livet. Tysk blev for ham det poetiske sprog, og på baggrund heraf må det vel ses, når han som gammel mand i skuffede vendinger omtaler et besøg i det kgl. teater i København. Dansk digtning og skuespilkunst opnår han i virkeligheden aldrig at komme rigtig på talefod med. Sin gode veninde, „digterinden Anna"s, små digte på dansk forstår han dog at goutere. Hans kone, hans elskede Wilhelmine, bjærgmandens datter fra Harzen, havde vel ikke samme åndelige ballast som han, men i musikalsk henseende har hun dog sikkert været ham overlegen; det er utvivlsomt fra hende, børnene, især Theodor, har arvet deres musikalske anlæg. Af landsbybørn at være fik de en god opdragelse. Det rent elementære lærte de i landsbyskolen, men tidligt kom de også til at nyde godt af pastor Lautrups undervisning. Han havde først været den ældre generations læremester og religiøse vejleder, og var senere også blevet det for Jens Wulffs børneflok. Foruden i religionen gav han undervisning i sprog, litteratur og andre almendannende fag. $\mathrm{Da}$ børnene voksede til, tog Wulff sig også selv af deres opdragelse. Han tog dem med på sine rejser, og de fik herved lejlighed til at stifte bekendtskab med teater og anden god kunst. Theodor W.s interesse for opera er sikkert blevet vakt på disse rejser med faderen. ${ }^{8}$ ) Alle sønnerne lærte at spille, og sammen med musikalske venner fra Brede og omegn dannede de med tiden et lille orkester, som holdt sammen gennem flere årtier, og som var med til at højne musiklivet på vesteregnen. Som regel sam-

8) Ang. Theodor Wulff som operakomponist se: Sønderjydsk månedsskrift 1949 , s. $166-171$. 
ledes orkestret en gang om ugen for at øve, og meget ofte fandt disse øvelser sted hos Wulffs. Ved disse sammenkomster - og også ved andre lejligheder - blev der tillige oplæst digte, som oftest tyede man vel nok til klassikerne, men også Christiane Lautrups („digterinden Annas") og Jens Wulffs digte og fortællinger blev læst ved disse lejligheder. $P a ̊$ sine ældre dage læste Wulff også jævnligt op af sine dagbøger.

Wulff giver ofte i sin dagbog udtryk for glæde over dette hyggelige og højnende hjemliv, især er han glad for de mange åndrige og opbyggelige samtaler med den gode nabo, pastor Johan Christian Lautrup og hans begavede datter Christiane, "digterinden Anna“. Hvad pastor Lautrup har betydet for det Wulff'ske hjem lader sig ikke let overvurdere; det var væsentligst for hans skyld, at Wulff satte bo i Brede og ikke forblev i Altona. Forinden Wulff sluttede sig nær til pastor Lautrup, var han dog nået frem til en fast religiøs overbevisning, men i sine samtaler med præsten og ved at lytte til hans prædikener havde han fået denne yderligere underbygget. Pastor Lautrup var rationalist, og man får ved læsningen af dagbøgerne et meget tiltalende indtryk af denne kloge præst og hans livssyn. Hans hovedtema var: Vis din tro i dine gerninger, og Wulff udlagde dette på den måde, at man skulde blive en nyttig samfundsborger, at man skulde ågre med de pund, Vorherre havde givet een at forvalte, og at man skulde tænke på dem, der led nød. Omsat i praksis vilde det sige, at man skulde hjælpe sine arbejdsduelige medmennesker til arbejde og fortjeneste, så at de blev nyttige samfundsborgere og ikke faldt fatigvæsenet til byrde. Det er blandt andet ud fra denne indstilling, at Wulff under Napoleonskrigene fortsatte sin kniplingehandel, endskønt han ikke under disse urolige forhold kunde regne med fortjen:z.e. For ham var hensynet til kniplepigerne her det afgorende. Også på anden måde tænkte han på sine kniplingepigers 
velfærd. $\mathrm{Da}$ sønnen Hochberg senere oprettede en kniplingeskole, understottede han ham hermed og giver ofte udtryk for sin interesse for sønnens virksomhed på dette område. At familien også har økonomisk interesse $\mathbf{i}$ uddannelsen og dygtiggørelsen af kniplepigerne, er en anden side af sagen. At hjælpe gamle, syge og fattige, som uforskyldt var kommet i nød, var noget, Wulff ud fra sit rationalistiske syn lagde megen vægt på, og selv om han i sin dagbog omhyggeligt og på en lidt farisæisk vis opnoterer sine gode gerninger, beholder man dog $\mathrm{i}$ erindringen det indtryk, at han mente sine nødlidende medmennesker det godt. Når han var hjemme i Brede - og navnlig på sine ældre dage, da han ikke mere var så meget på rejse - var han meget flittig til at aflægge besøg hos gamle venner og bekendte, som sygdom holdt bunden til stolen eller sengen. Til fattige havde han som regel en foræring med, og nu og da arrangerede han små festligheder $\mathrm{i}$ fattighuset. Når han besøgte skolen, havde han altid godter med til børnene. Som et eksempel på Wulffs moralske habitus kan endvidere nævnes, at da det foråret 1837 mange steder blev stor mangel på hø og mange kreaturer rundt omkring døde af sult, lånte han, der havde hø nok, af sine beholdninger ud til dem, der intet havde, endskent han let havde kunnet sælge høet til tredobbelt pris. Ordet: Vis din tro i dine gerninger, var for ham ikke blot mundsvejr.

I almindelighed siges, at rationalisternes gudsforhold var ret overfladisk, men man vilde gøre Jens Wulff uret ved at hævde dette om ham. Smuk og mandig er den måde, han i sin dagbog giver udtryk for sorg, når sygdom og død har ramt hans kære. Da hans lille søn Theodor dør 1818, kan han slutte nekrologen med et "Herren gav, Herren tog, Herrens navn være lovet", og da hans elskede datter Dora i 1854 i løbet af en måned mistede fire børn af skarlagensfeber, henviser han til, at man også i denne ufattelige store sorg "maa finde sig i Herrens førelse og tro, det saaledes er bedst, som han tilskikker os det, om hans veje end ei ere vore“. Ud fra en dybt forankret tro på, at der er en højere førelse til, må hans liv og virke ses. Det var denne tro, 
som havde hjulpet ham gennem vanskelige undomsår, og det var fra dette ståsted, han kom til at ove manddomsgerning.

Wulffs rationalistiske eller forstandsbetonede indstilling kom også tydeligt til udtryk på det politiske, og især på det nationalpolitiske område. I politisk henseende vil man nærmest kunne karakterisere ham som gammelliberal. Han er klar over, at den absolutte monarkiske styreform har overlevet sig selv, og han onsker moderate reformer i landets styreform gennemført. Under omtalen af den franske julirevolution i 1830 giver han et par gange udtryk herfor $i$ dagbogen. Han håber, at himlen vil give magthaverne forstand og vilje til at føje sig efter tidens krav og lette folkene deres byrder, ellers må man regne med oprør alle vegne (27/9 1830). Direkte møntet på danske forhold skriver han $31 / 12$ 1830: „..... Ogsaa i hertugdømmerne Schleswig-Holsten vare ved aarets ende uroeligheder og megen bevægelse, thi ogsaa her vil mand ey længere nøyes med det gamle, ogsaa her føler folket dets myndighed og vil have deel i bestyrelsen. - Dog den gode konge vil vist ikke sætte sig imod folkets vilie, men vil indsee, hvad der tiener til hands og til folkets ford[el].“ Wulff ser da også med glæde på udvikingen i 1830'erne. Han er glad for, at de besiddende klasser ved stænderforsamlingernes indførelse får indflydelse på den politiske og økonomiske udvikling, men 40'ernes krav om et egentligt folkestyre med lige og almindelig valgret er ham inderligt imod. En kongemagt, bistået af rådgivende stænder, var hans politiske standpunkt, og i Christian VIII fandt han en sådan konge, en oplyst monark, som sammen med stænderforsamlinger kunde styre riget til folkets gavn. Især efter at han har opnåt personlig kontakt med Christian VIII og hans dronning Caroline Amalie, strømmer dagbogen over med hyldest til majestæterne. It par af højdepunkterne nås, da Wulff 1846 får tildelt fortjenstmedaljen, og da kongeparret 1847 aflægger besøg hos ham i Brede. Dyb og ægte er hans sorg, da han 25/1 1848 skriver mindeord over Christian VIII i sin dagbog. 
Overfor 1840'ernes nationale strømninger i kongeriget og hertugdømmerne står Wulff fremmed. Han var helstatsmand, d. v. s. han ønskede den dansk-tyske helstat omfattende kongeriget og hertugdømmerne opretholdt. Vel var han dansk, og dansk var hans modersmål, men hans åndelige kultur og dannelse var overvejende tysk, og gennem sit virke som kniplingskræmmer havde han fundet sig mange venner og forretningsforbindelser mod syd. Dlet var ham ulideligt at tænke på, at det nationale røre $i$ hertugdømmerne og $i$ kongeriget skulde medføre, at disse venskabsbånd måske kunde sønderrives. Af betydning for hans stilling var givetvis også, at hans handel vilde lide skade, om Holsten og evt. Slesvig blev udskilt fra det danske monarki. Derfor vil man også kunne forstå, at Wulff ikke var nogen ven, hverken af det nationalliberale parti i kongeriget eller det slesvig-holstenske parti i hertugdømmerne, og skarpe er de udfald, han retter mod begge parters agitatorer. Vi er vant til at se 1830 'erne og 1840'erne skildret som den tid, „Da Sønderjylland vågnede", som en tid, da store dele af den nordslesvigske befolkning blev sig dansk bevidst og krævede Sønderjylland regeret på dansk; for Wulff var de danske talsmænd ligesåvel som de slesvig-holstenske agitatorer urostiftere. Treårskrigen kom derfor ugsả til at stå som den store skuffelse for ham. Den blev for ham et opgør mellem landsmænd, mellem brødre, og i sin dagbog fra disse år vender han bestandig tilbage til tiden forud, der skildres som en lykkelig tid, da danske og tyske "kunde vandre $i$ endrægt med hinanden haand $i$ haand“. Et sted skriver han: „... og er mig tysk som dansk lige kær, hvor ieg finder retlig sindelag; agter enhver, der føler varm for sit fødeland. Kuns maa efter min anskuelse og fornemmelse fædrelandskærlighed ei udarte til had og forbitrelse mod andre nationaliteter ....". Men det var ord, som ikke var populære, og vel heller ikke kunde være det, i en tid, da afgørelsen måtte træffes på slagmarken.

Rent menneskelig blev Treårskrigens tid trist for ham, da 
der nu også drages politiske skel inden for hans familie- og vennekreds. Svigersønnen, apoteker Nagel i Højer, var en af de nationalliberale førere på vesteregnen"), og også sønnen Ferdinand og veninden Christiane Lautrup lod sig rive med i den nationale rus. Det kan ikke undgås, at det kommer til sammenstød med dem, men på den anden side er Wulffs familiefølelse dog så stærk, at han gennem sine forbindelser i den tyske lejr gør alt muligt for at få svigersønnen befriet fra sit fangenskab. Hårdest i sit ordvalg er Wulff overfor nogle af egnens nationalliberale præster og herredsfoged Brasen, som han tidligere var kommet en del sammen med.

Wulff forstod ikke, at tiden og udviklingen gik ham imod; han var helt et barn af den rationalistiske tidsalder, og nationalt og religiøst kunde han ikke følge med. I de senere år bliver han derfor mere og mere indadvendt, og en af hans kæreste sysler bliver at genopleve sit lange og bevægede liv $i$ erindringen ved læsning i dagbogen. I legemlig henseende begyndte alderen nu også efterhånden at gøre sig gældende. Han havde alle dage kunnet rose sig af et godt helbred, og endnu i 1850'erne er han ofte ude på lange rejser, selv om en dårlig fod nu og da kan lamme hans bevægelighed. I de unge år havde han fået en enestående træning $i$ lange fodture, og selv om han senere red eller kørte med et par raske heste pă sine handelsrejser, holdt han sig dog fremdeles i god træning. Endnu da han nærmede sig de firs, vandrede han ofte fra Brede til Højer og tilbage på en dag, og vejret skulde være meget dårligt, om han ikke kom ud at se til sine marker.

Han overlod efterhånden mere og mere af forretningerne til sine sønner, men han fulgte stadig levende med $i$, hvad de foretog sig. Til nogle få dage før sin død d. 23. marts 1858 førte han med rystende hånd dagbogen, og til det sidste var hans ånd usvækket.

9) Ang. apoteker Nagels oplevelser under Treåarskrigen, se Nordslesvigsk S $\varnothing$ ndagsblad $1910 \mathrm{nr} .47-51,1911 \mathrm{nr}$. 1-3. 


\section{Uddrag af Jens Wulffs dagbog}

\section{Kosakvinteren 1813-14.}

$181331 / 12 \ldots$. Og saa endte sig da dette aar under udsigter, der for det danske land ere sørgelige, og for dets beboere skreksom. Endnu ingen sinde saa det saa farlig ud i de sidste 100 aar, som ved slutningen af dette aar. Talrige fiender ere $i$ landet og have alt erobret heele Holsten og en del af Schleswig med, og Krigens ødeliggende følger hviler allerede svært paa disse egne; det øvrige af det schleswigske og Iylland med trues med samme skiebne. Forfügender til landets forsvar ere svage og svankende; der hersker overalt ingen bestemthed, ingen fasthed, og det lacier ingen plan. Fæstningerne ere ey forprovianterede, armeen ey forsynet med det nødvendige og er disverre uden anfører. - Nationens utilfredshed er stoer; svære byrder bar mand i mange aar, som den stoere militairmagt paalagde folket, og nu da mand skulde høste frugter heraf og finde forsvar mod fiendtlig overfald, bliir den eene provinds given priis efter den anden, og fiendens vilkaarlige behandling overladt, der efter alle berettninger ey ere talriige. Mand marsierer med iilmars fra Sielland til det schleswigske, da fienden alt havde en deel af denne provinds og havde Holsten i sin magt, og nu løber mand liige saa iilfærdig tilbage uden at have udrettet eller forsøgt noget. Det heele er et virvar, som ingen kand blive klog paa, ingen finde reede $i$, og himlen give, mand maatte bequemme sig til at giøre fred, da mand ey forstaar at føre krieg.

$18149 / 1 \ldots$ Denne dag var meget urolig, spendt og forventningsfuld; i aftes modtoge vi efterrettning, at kosakkerne vare i Tønder; formiddagen kom Andr. Hansen fra Tønder og bragde samme efterrettning, og det hedder tillige, at de ville passere her 
igiennem efter Riibe. Middag heedte det, at mand kunde see dem ved Sølvsted kroe, og alles frygt og forventning var stoer. Ingen gudstieneste blev holdt, og alting var i forstyrring. Søster Kirstine var i dødsangst og flygtede til Brede, enhver havde tilsidebragt sine bedste ting, ogsaa vi havde giort det samme, saavel i Brede som i Bredebroe. Dog mand havde taget feil, og der kom ingen endnu i dag; vi haabede, at de maaske havde taget veyen over L. Closter.

1814 10/1 . . Endnu i dag kom der ingen kosakker; de ligger endnu i Tønder; frygten begynder nu at tabe sig noget.

$181411 / 1$. . I I aftes modtoge vi uventet ved S. Petersen den efterrettning, at der erfred, og den tiidende indløb fra alle siider; en kosak passerede giennem fra Riibe til Tønder og tilbage.

$181412 / 1$... Var i dag i Tonder med M. Winter. Lod vore heste staae ved kirkegaarden, blev ikke anholdt eller noget sagd af kosakkerne, der ere meget skikkelige folk og fører sig rett got og - endnu ingen bestemt vished om freden, og dog erholder sig rygtet, at freden skal være der, og de fleste haabe og troe herpaa. Gud give det haab og den troe maatte gaae i opfyldelse. I Tønder bleve heste leverede af Tonder og Kloster amt, ogsaa af Riibe amt er tilsagd.

$181413 / 1 \ldots$. Var eftermiddag til flytthytte til Chresten Nielsens. Uanset de mange mennesker i den lille varme stue, kunde vi dog ey faae vinduerne til at viige. Dandsede lidt og vare rett fornøyede. Kom hiem kl. 11.

$181414 / 1$.. Uventet besøg af L. Hansen og kiøbmand Stein fra Tønder. De vare udsendte at kiøbe lidt, requireret af russerne; efterrettning, at der var kommen 40 mand svenske til Tønder. Kommandanten af Tonder passerede her igiennem til Riibe .....

$181415 / 1 \ldots$ Kulden bliir nu næsten uudstaaelig, alting

1814 9/1. L. Closter = L $\varnothing$ gumkloster.

1814 13/1. Flytthytte = flyttegilde. 
fryser inden dørre; en kiedel med vand stod denne morgen frossen ved kakkelovnen; det er en græsselig haard vinter.

1814 16/1 . . Fredrygten vedholder sig endnu, og de fremmede tropper trække sig nu synder paa. ...

$181417 / 1$... Var i dag i Tønder med fader Trenckner og Julchen at see kosakkerne, men da vi kom til byen vare de alt borte; dog kom der snart en trop igien, som var passeret Bredebroe og kom fra Riibe. Modtog da nu endelig den sikre og bestemte efterrettning, at der er fred, og de fremmede tropper, der ere i landet, ere ey fiendtlig meere. Himlen være tak, at mand nu igien roelig og sikker og tryg kand boe i sin hytte. De fiendtlige tropper have ellers været meget flittige ved at requirere og især heste. $\mathrm{Nu}$ er der bleven forlangt $20000 \mathrm{c}$. af Tønder bye og 18000 c. af amtet, som vil blive svart og trykkende for egnen, om de skal udredes. ... Søster Kirstine var meget syg af skrek over de igiennempasserede kosakker.

$181425 / 1$. ... Den haarde vinter vedvarer, den største haab kand ey bringe vinduerne til at tøe det mindste op, $i$ den lille stue er væggen og loftet i det syndre fag overtrokken med is ...

$18147 / 2 \ldots 300$ mand polakker lancierer kom til Tender, og som det hedder, skal der følge meere. ...

1814 16/2 . . . [på rejse] I Bramsted spaaede mand meget ilde at komme igiennem de fremmede tropper eller kosakkerne, som forfarer næsten liigedan mod ven og fiende - og da der mødte mig 3 humlevogne $1 / 2 t$ [ime] hiin siide Bramsted, som fortalte, at en trop kosakker vare ved næste værtshuus og tillige mente, det var farlig for en ensom reisende - saa vilde ieg ey forsættlig udsætte mig for.nogen fare - men vendte paa stedet om og reed tilbage til Kellinghusen .....

\section{6.}

$183612 / 3$. . . skrev til ... apoth. Erdmann i Harzgerode . . .

1814 7/2 Lancierer = lansenerer.

1836 12/3: Harzgerode i Anhalt, syd for Quedlinburg. 
angaaendes det proiecterede anlæg af en runkelrors zukerfabrik, hvorved Ferdinand kunde vorde beskieftiget, mueligt Theodor med, og vi kunde see vore børn placerede hiemme, hvilket vi saa inderlig ønsker, men maaske er det heele blot et luftproiect, at mand udbassune som sikker og profitabel, hvad der er riskant og tvivlsom, at rowen her ey vil trives eller mangler de sukkerdele, iordbunden samt luften meddeler den $\mathbf{i}$ sydligere egne. - Men nøye undersøges skal dog denne ting og hvis forsøg love en nogenlunde gunstig resultat da iværksættes. Meget interessant kunde et slig anlæg være mig og os alle, derved saare gavnlig for omegnen. Bonden kunde faa bedre udbytte af $\sin$ iord og mange hænder kunde vorde beskieftiget.

$183622 / 3 \ldots$ Afsluttede i dag med Hochberg, som blev færdig med sine ting og var sieleglad ved sin afregning, der gav et ulige bedre resultat, som han havde ventet; havde et overskud af $1850 \mathrm{mk} .$, som han tør kalde sine og seer derved opmuntret, glad og haabefuld den kommende tid imøde.

America kom ham got til hielp, ellers vilde han kuns have havd ringe overskud. - Lovet være Gud, at ieg saa meget kand lætte mine børn deres begyndelse, at ey deres mod og vedholdenhed tør sættes paa saa haarde prøvelser som mit; sandelig! ieg maatte gandske anderledes kiempe og anstrænge mig, før ieg kunde kalde $1850 \mathrm{mk}$. min eiendom, og disse kunde ieg endda kuns bruge til forlættelse af mine forældres trange kaar.

1836 18/4 .. . Havde den glæde at modtage brev fra broder Hans med den gode efterretning, at han er bestaaet med ære som alderspræsident ved forsamlingen af stænderne $\mathrm{i}$ Wiborg og der finder den anerkiendelse, som hans hoved og hierte fortjener. Han bliir nu en udmærket mand, har leilighed til at anvende sine sieldne talenter og vil vist meget kunde gavne sit fødeland. ... .

$18369 / 6 \ldots$ derefter til mit kiere hiem, hvor ieg fandt stoer ødelæggelse. Huuset afbrækket fra forstuen af til sønden paa enden nær. Vort sovekammer er i laden, og det seer vidtløftig 
og forstyret ud hos os. Gid vi havde alting i stiil og orden igien.

$183610 / 6 \ldots$. Grunden blev efterseet til vester. Den sorte hedeiord bort -, sand og gruus ikiort, grundsteen lagd.

$183611 / 6 \ldots V i$ har ved voores aabne huus en herlig tid ypperlig veyr. Eftergav min kones onske at faae vores bygeverk mere fuldstændig, da det endnu er tid at udvide og forfuldkomme vores plan, paa det vi siden intet har at fortryde, andre intet at dadle. - Loft og gulv blev derfor opbrækket $i$ salen og hammeren $i$ den synder ende nedtagen. Bygningen skal nu forhøyes til og med quisten. De øvrige 5 fach, saa vil Gud, næste aar. Grunden blev optaget og vel forsynet ved den øster side.

$183614 / 6 \ldots$ Tog til Brede, hvor mand havde begyndt at mure, men som ieg igien lod tage op; - vores bygeplan forandres nu gandsike, og ieg faar give efter for det almindelige ønske at bygge skiønnere, større og rummeligere, da alle dadler det snevre lave huus. Kone og børn, venner og naboer skal nu faae deres onsker opfyldt - et hoyere og videre huus skal nu vorde opført og intet spart; ieg giør dette nu med glæde, da jeg seer i stæden for at misunde mig en skiønnere bolig, som nogen her paa egnen har, mand endnu ønsker og under mig c'g min familie en smukkere. Kiert, meget kiert var dette kiendcmerke mig, at ingen misunder mig min lykke, mine bedre kaar, at mangen een og de fleste paaskiønner, at ieg ved min virksomhed gavner og har gavnet, at mand under mig at høste og have høstet frugter af min fliid.

Huuset bliir nu 14 al viid, høy paa muuren; for at faae tør huus, frie for fugt og svamp, skal det inden til $3 / 4$ alen forhøyes, en foed af 2 steens muur til samme høyde, gothiske vindver - høy dør med trappe af hugne steen, og jeg haaber at faa det net og smagfuld, men frielig vil det koste mange, mange penge. ...

$183611 / 6$ hammeren = gavlmuren. 
$183616 / 6$... Vi bleve i dag ende'ig færdige med nedbrækning og begyndte at lægge grundsten. Besluttede for at give salen mere styrke og bedre proportion at bygge den 4 fag til $2^{1 / 2}$ alen viid og medhen rykke 2 alen ind, hvorved vi tillige faar bedre, fastere grund; tillige besluttede at fordele breden til begge sider og ey, som først planen var, lade det hele træde ud til den vestre side....

1836 18/6 . . . Tog med Dora til Chr. Albr. kog, hvor ieg fandt Hochberg og Ferdinand beskieftiget med at belade 3de skibe med resten af vores uld, og hvor den fatale Distel er at passe paa og veye, hvortil mand maatte laane vores vægt, og hvilket gav saa megen forsinkelse, at skibene ey kunde vorde tilladte og expederede $i$ dag.

$183626 / 6 \ldots$ Med vores bygeværk blev planen ændret. Stadager giorde en anden indrettning, greb ind $i$ det gamle huus, som skal bygges næste aar. - Quisten gaar et fag længer til synder og alt kand derved blive smukkere, bedre saavel inden som ude fra. Got det endnu var tid, men ogsaa paa den høye tid at giøre den afændring, saa mand for den kommende tid ingen bebreidelser tør høre eller giøre sig. - Mand har io slet ikke været betænkt paa dette saa meget udvidet bygeværk og har tillige hverken tid til eller sands for at sysselsætte sig med sligt, da denne tid er saa meget at tage vare paa ...

$18369 / 7 \ldots$ Vi reiste i dag huus og havde et sælskab af hen til 78 mennisker, som alle vare rett glade og fornøyede og holdt ud til kl. 4 om morgenen. - Vore sønner med 2de musici fra Kloster bidroge meget til at forhøye glæden og de fleste af selskabet hentede hos os trætte been. .. .

$18362 / 8$.. . Vores pavillon blev paa foden nær færdig i dag - stellage nedtagen. Vinduerne med det farvede glas isatte, og vi havde talrige besøg af nysgierrige for at see vore ting. Alt

1836 26/6 Stadager = Bygmester Nicolay Stadager fra Højer.

1836 9/7 Kloster = Løgumkloster. 


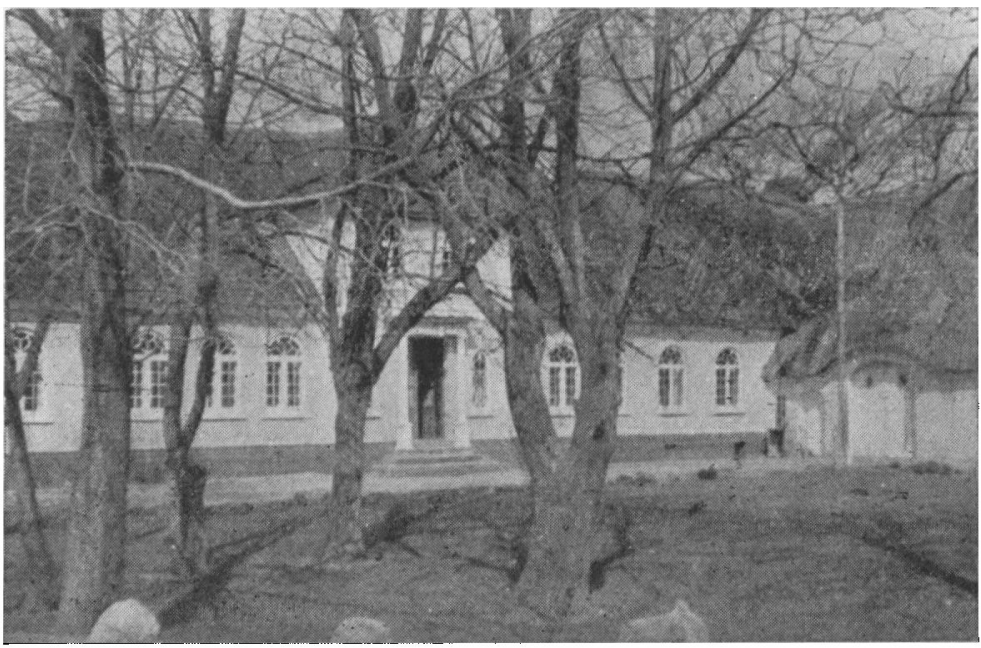

Fotografi af Jens Wulffs hus kort før branden

fandt biefald og opvakte beundring, især det couleurede glas, som i denne egn ey før er seet.

$183631 / 12 \ldots$. Gud skee lov, at vi i aar atter kunde glæde os til fred i vort land, og at loven var i samme den herskende magt. - Ved vore stænders forste forsamling blev folket given en nye impuls, der nu ogsaa lærer at tage deel i det offentlige. Hidtil kymrede med faae undtagelser enhver sig blot om det in[divi]duelle og sig selv. Det vil sikkert hæve nationen, at enhver som besidder eiendomme, finder sig berettiget til ved stænderne at tage lidt deel i bestyrelsen, da han enten kand vælge sin repræsentant eller blive valgt og derved have indflydelse paa lovgivningen - kand giøre opmærksom paa det mangelfulde, som lovene, som bestyrelsen, maatte være underkastet.

Min ældste broder udmærkede sig som medlem af stænderne $i$ Wiborg meget, vandt sig almindelig agtelse og hans navn vorder hyldet overalt i landet. ...

Aaret var ikke frugtbar, og især havde vi en daarlig høst, 
da ved den idelige regn sommerkornet kom daarlig og bedervet i huus. - I England og Nøramerica skal høsten endnu have været slettere, meget korn udskibes didhen og priiserne af fødevare stege. - Ruggen kostede ved aarets ende $9 \mathrm{mk}$, byg 6 à $6 \mathrm{mk} .8 \mathrm{~s}$., havre $3 \mathrm{mk} .12 \mathrm{~s}$. à $4 \mathrm{mk}$., boghvede $5 \mathrm{mk}$., kreature blive søgde. - Flæsk, smør, uld og andre producter var høy i priis, og i det hele var det for landmanden en gunstig tid, - ogsaa steege eiendommene saavel i kiøb som i leie.

Ved tilfældige omstændigheder blev min uldhandel udmærket stoer og vigtig dette aar. Vi kiøbte allene mærskuld hundred tusinde pund - iydsk 10000 pund. - Meget arbejde, megen uroe, sorg, ærger og fortred bragte denne handel med sig, og skiøndt der frielig blev fortient noget, saa skiøttede ieg dog ikke om at gaae denne skole igiennem igien.

Vores bygeværk giør dette aar tænkelig. 10 fag stuehus blev nyebygget og kontrasterer stærkt mod det gamle. En havemuur med pavillon blev ligeledes opført, hvilket alt kostede meget, men blev tillige smukt. Kuns skade, at der endnu er saa meget tilbage, som vi nu tvinges til at bringe $i$ harmonie med nyebygningen.

De mange ubehageligheder, som handelsnid forvoldte mig i Jylland forrige aar, endte sig dette aar tilfredsstillende og ærefuld for mig. Over byefoged Nellemann i Holstebroe fik ieg revange, hans dom med hensyn til caffesagen blev underkiendt, og for at betrygge mig for chikane med hensyn til uldhandelen meddeelte mig cancelliet consens, frit og ubehindret at kiøbe og sælge uld, naar og hvor ieg vil i hele riget.

Kniplingshandelen var flau, dog gav America endnu skikkelig udbytte, kun tegner det sig der ringe for den kammende tid.

For Wilhelm aabnede sig nye afsadskilder for sine strømpevare til Nør America, hvilket maaske kand give denne handel

$183631 / 12$. Caffesagen. Denne sag ses iøvrigt ikke at være omtalt i dagbogen. 
en gandske anden rettning. Gid derved en bedre priis og meer arbeidsløn for de stakkels bindere maatte kunde tilvejebringes.

Vores projecterede runkelror sukker fabrick kom ey til udførelse, hvilket sikkert var til hæld for os.

\section{7.}

$183727 / 3 \ldots$. Rohde gav denne efter middag koncert i skolen ved Bredebroe understattet af Ferdinand. Der var 13 musici og over 100 tilhørere. Hvor det var en fornøyelse at varetage den stilhed, roelighed og opmærksomhed, som herskede i forsamlingen, hvilket sandelig giorde vort publicum ære $\mathrm{ng}$ mægtig kontrasterer med den støy og snak, som pleier at finde sted i Claster, naar der gives koncert.

$18371 / 4 \ldots$ Og ligesom marti var en vinter maaned begynder april i samme spor. Det seer sørgelig ud for de arme kreature, da overalt er stoer fodertrang og der er stoer nod. Mange kreature skal allerede være død af mangel og elendighed, men langt flere vil krepere endnu, især om denne tid skulle holde ved og foraaret ey snart vise sig. Faar skal især krepere til tusindtal, og mærskmanden især geraade derved i stoer elendighed, seer sit haab, sine trøstende udsigter gandske skuffet. Hvor lykkelig ere vi, ey allene at have overflødig foder for vore kreature, men endog at kunde hielpe mange. Vi begyndte $i$ dag at udlaane vores he og 6 bleve reddede af deres nød, til deels uden at haabe det og paa en overraskende maade - $\mathrm{i}$ det mindst 3 gange er denne $\mathrm{t}$ id det værd, hvad vi laaner ud, imod hvad vi faar igien, og mange penge kunde vi have giort ud af vores høeforraad, men langt være det fra at benytte mig af andres nød og forlegenhed - min vinding være den at hjælpe i nød, og denne vinding er mig mere værd end timelige fordele. ...

1837 27/3 Rohde $=$ Amtsmusiker Peter Petersen Rohde fra Løgumkloster. 
$183723 / 4 \ldots$ Hochberg og Ferdinand ... kom tilbage fra deres mærsktour. Det seer der med faare flokkene sørgelig ud. Vel den halve deel er død, for en deel af sult, da langt flere faar vare tillagte, som mand kunde føde, mange ere ogsaa druknede, især har den sidste vinter for 8-10 dage siden kostet mange hundrede, vel tusinde livet. - Gravene vare tilfrosne - dog kuns belagt med et tyndt lag iis. Dette med ageren var bedækket med snee, de arme dyr fandt her en fælde - kom paa den falske iis, plumpede igiennem og 7 a 8 stk. fandt mand liggende død hos hinanden. Det vil give ringe uld dette aar, som vil faae en ringe priis. Hvor lykkelig vare vi dog forgangen aar, at veyerligget var saa gunstig, faarene saa sunde og ulden saa god. - Et foraar som dette kunde have giort os ulykkelig ved de stoere parthier, vi havde kiøbt, de mange penge vi forud havde betalt; nei! sligt vovestyk giør ieg aldrig mere, lad saa kiøbe hvem der vil, thi ogsaa commissions handel kand blive faerlig, da mand io alletider staar til ansvar.

$183730 / 4 \ldots$ Maanedens halve deel var en sand vintermaaned, men om saa ønskeligere blev veyerligget fra den $15 \mathrm{de}$ af. Det saa ud til, at de arme kreature vilde døe af sult, da overalt var fodertrang, men grøden kom med en fart. - Deilig grøn er ved maanedens ende ionden. Kreaturerne finde alt tilstrækkelig føde og kand forvinde deres nød igien. Engene have alt et meget lovende syn, og med trylleslag er foraaret der; saa kand mangen gang alt blive saa got, seer det endog nok saa vanskelig ud. ...

$18376 / 6 \ldots$. . Her i egnen grasserer den saakaldte typhus, som meget beuroliger mig.

$183716 / 6 \ldots$ Der blev i dag plantet runkelroer $\mathrm{i}$ toften og osten huset .......

1837 16/6. Når det i Det blandede Distrikts Landboforenings jubilæumsskrift (1954), s. 52 hedder, at Kresten Knudsen, Visby Hedegård, var den første, der dyrkede roer i Vestslesvig, er dette altså ikke rigtigt. 
1837 16/9 [København] . . Hans besøgde Oersted og var indbuden hos etatsraad Bech, saa ieg denne eftermiddag havde det ene, hvilket for mit skriverie passede got.

1837 17/9 [Kabenhavn] .. . Var om formiddagen i Runde og Fruekirke, men kunde for den stærke gienlyds skyld ey forstaa noget af prækenen, heller ikke høre sangen for den stærke gienlyd af orgelet ...

1837 20/9 [København] .. . Var i dag lidt omkring i byen og paa den runde taarn, hvor mand har et meget smukt panorama af Kiabenhavn og omegn. Var aftenen til comedie, hvor Christen og Christine idyl og Nina pantomime og ballet blev given, fandt et meget smukt skuespilhuus, dog ey stoer. Orchesteret var got besatt og vist fortrinlig, ligesom og skuespillerne giorde deres ting meget got og især dandsede fortræffelig. Dog vilde det danske sprog paa theatret slett ikke tilsige mig, men det er io og saa uvan, idet det var første gang, ieg paa saadant sted hørte samme tale.

$18373 / 10$ [København] . . . Var til Høyeste ret og bivaanede en session, men saa lidt den forhandlede sag som local og personel tilsagde mig, den blev langt under min forventning.

1837 13/11 [Kabenhavn] ... Min broder havde i dag audience hos kongen og blev meget naadig modtagen. Han befinder sig i dag Gud skee lov bedre og var aftenen hos professor Schov, Wiburg ständerforsamlings præsident. Det er overordentlig saa renomeret min broder er, overalt kiender, overalt agter mand ham, og han oplever sandelig en lykkelig alderdom, helst sligt saa meget tilsiger ham.

1837 16/9. Efteråret 1837 foretog Jens Wulff sammen med broderen Hans W. en rejse til Norge, Sverige og Bornholm. Den udf $\varnothing$ rlige rejseskildring er udeladt her. Oersted $=$ juristen Anders Sandøe $\emptyset$ rsted. Bech $=$ deputeret $\mathbf{i}$ told- og kommercekollegiet $\mathrm{H}$. Bech.

1837-20/9. Christen og Christine, dramatisk idyl, oversat af J. L. Heiberg efter Scribes og Dupins Michel et Christine. Nina eller Den vanvittige af kærlighed, ballet af Bournonville. 
1837 14/11 [København] ... Broder Hans løb omkring og besøgte de stoere. ...

1837 16/11 [København] ... Var aftenen til comedie, hvor Svend Dyrings huus blev given for fuld huus, men som ey synderlig morede mig, da ieg kuns forstod det mindste af, hvad der blev sagd og var for lang udtrukken.

$183731 / 12$.. Saa haardt foraaret ogsaa var, saa længe ud paa aaret vinteren ogsaa vedholdt og saa vanskelig det og saa ud med den kommende høst med føde for mennisker og quæg, saa blev alting dog got. Vi havde en rett behagelig sommer at glæde os til og blev høsten ogsaa ikke riig, saa var den dog tilstrækkelig saavel at sikre mennisket sin føde som huusdyrene deres foder.

Priiserne paa korn bleve middelmaadige. Rug kostede fra 6 til $7 \mathrm{mk}$., byg $5 \mathrm{mk}$., havre $2 \mathrm{mk}$. $8 \mathrm{~s}$. til $3 \mathrm{mk}$., boghvede 4 a $4 \mathrm{mk} .8 \mathrm{~s}$. Høe havde mand i denne egn rigelig dette aar ...

Sands for det almindelige tiltog ellers stærkt i vort land, og mange stemmer yttrede sig med friemodighed over landets anliggender, fremkaldt af stænderforsamlingerne, hvor mange ting bleve offentliggiorte, mangen feil i lovgivning og forvaltning paapeget og derved folket vakt af dets letargie.

I handels henseende var aaret ikke ugunstig. Uldhandelen bragte et temmelig got resultat. Kniplingshandelen gik taalelig og lod til at tegne sig bedre for den kommende tid, helst Hochberg saa gandske vidner sig denne brange og lader til at faa held til at tegne smukke mønstre. Det er derfor ogsaa til gavn, at han har ladet en pige, Bold Marie Pallesen, oplære at slaae mønstre op og prikke breve til samme.

Tænkelig for mig var min reise i sælskab af broder Hans til Norge, Sverig og Bornholm. Reisen $\mathrm{f} r$ a Bornholm, de vanskeligheder og farligheder vi havde at kiempe med paa denne fart i den stormfulde tid havde snart giordt ende paa vore dage.

$183731 / 12$ letargi $=$ lethargi $=$ døsighed, dorskhed.

På tilbagerejsen fra Bornholm kom skibet ud i stærkt storm. 
1838.

1838 13/3 . . Fra Høyer modtog ieg det i handelshenseende ublide budskab, at V. udsændinge har været i Høyer, gaar dør for dør og byder $20 \mathrm{~s}$. for ulden. Det seer nu ringe ud ogsaa med denne brange, og mand har at see sig for $\mathrm{i}$ aar ey at give til priis, hvad mand før har tient.

$183829 / 4 \ldots$. Det seer i aar igien sørgelig ud for de stakkels kreature; paa østerkanten skal der være stoer fodermangel. Kreaturerne gaae der ude og mange dør af mangel! ...

$18381 / 6 \ldots$ Tilbage ... til Brede, hvor vi fandt alt saa pyntelig og nett, som vores byggerie virvar vilde tillade. - Grundvolden fandt ieg lagd paa nørrenden nær, da vore grundvoldsteen ey havde været tilstrækkelig.

$183826 / 6$. . . Fik vi i dag vores nye bygning reist, som Gud skee lov uden nogen vanheld kom i høyden, og hvortil vi have deilig veyr, skiøndt meget varmt. - Vi havde talrig selskab, vel 80 persohner ...

1838 25/7 . . I dag kirkevisitation, hvori provst Rehhoff første gang her visiterede. Han holdt en smuk og passende tale og lade til at være en vakker, veltænkende mand, der fandt sig saare tilfredsstillet med alt, der vedkommer hans fag. - Tækkeren begyndte paa den nørre og øster side for at dække vores høe.

$18387 / 8 \ldots$. Vore 3 sønner toge formiddagen til Closter for i morgen at spille til concert. ...

1838 29/9 [Hamburg] . . Var aftenen i St. Pouli til kommedie, bornene til behag; thi mig gouterer denne fornoyelse ikke mere, især naar saadanne stykke som Debutanten bliir given, der kiedede mig ....

1838 31/12 [Hamburg] . . Aaret var i det hele got og frugtbar, skiøndt veyerligget noget vanskelig $i$ høsten. Kornpriserne vare

1838 25/7. Johs. Andreas Rehhoff, provst over Åbenrå provsti, hvortil Brede hørte.

1838 29/9. Børnene = Ferdinand og Theodor. 
gunstige for landmanden ved aarets slutning, rug $9 \mathrm{mk}$., byg 7 mk., havre $4 \mathrm{mk} .8 \mathrm{sk}$. á $5 \mathrm{mk}$., boghvede $5 \mathrm{mk}$. 一. Creaturerne vare got i priis og var i mange aar ey saa dyre. Hæste, sviin og faar og uld ligesaa, og alt, hvad landet frembragte, blev got betalt, hvilket gav grundeiendommen høyere værd.

I handelshenseende havde ieg aarsag til at være tilfreds med dette aar, uldhandelen blev betydelig og vi kiøbte over $100000 \overline{\mathbb{H}}$, Wilhelms strømpehandel florerede, og Nør Almerica, hvor disse vare finder megen biefald, lover ham en varig afsadskilde; at han ved aarets sluttning allierede sig med $\mathrm{H}$. Lauritzen og Frey, vil vist giensidig være til stoer gavn. - Kniplingshandelen var ey saa gunstig for Hockberg, da America kuns bragte lidt - Dog var afsadsen paa fastlandet ey saa ringe. - Vi byde i aar meget. 15 fag blev tilføyet vor nye bygning, en nye overdeel kom paa stalden etc., som kostede mange penge og gav vores gode moder meget at vare paa, men vi har nu ogsaa et saare skiøn og meget bequem huus, hvis lige mand paa landet sielden finder. .... .

\section{9.}

1839 2/1 [Hamburg] ... Den meget artige Beneke indbød mig til at bivaane Ole Bulls concert, hvilket jeg antog og tilbragde i Hamburg skuespilhuus en rett behagelig aften. Huuset var overfyldt af mennisker, og $\mathrm{O}$. Bull høstede overvættes biefald. Hans kunst kand jeg ikke bedømme, men hans færdighed el stoer, kuns egner hans frembragde kunsttoner sig ey saa rett for gamle ører, saa lidt som størstedelen af nutids music. Den sterste vinding for mig er altsaa dette, at ieg kand sige at have hørt Ole Bull.

Ole Bull er langt yngere, som jeg havde tænkt mig ham og seer ud til at være mellem 20 og 30 aar. Hans udvortes er behagelig, godmodig og beskeden, og konstnerstolthed sporer mand ikke hos ham. Han er lidt tvungen i sine bevægelser, der vidne

1839 2/1. Beneke = en af W.s handelsvenner i Hamburg. 
$\mathrm{cm}$, at han i sin ungdom ingen dannelse har havd; ogsaa er han jo opdragen som bondedreng i Norge. Blomsterkrandse med digte bleve ved sluttningen nedkastede paa theatret og applaus hørtes fra alle sider, hvilken bifald maa glæde den gode Bull.

$183911 / 1 \ldots$ Men græsselige storme have raset her. Floden har endnu været høyere oppe som 1825 og langs kysten høyt oppe i landet - Apterp, Wollum, Døstrup etc. - marker, agger og eng belagde med uhyre iismasser. Mange huuse og bygninger ere ilde tilredte, til deels bortrevne. - Raskes og Lorens Hansens her i byen see ilde ud, især sidste, hvoraf flere fag ere gandske nedrevne; vester og nør paa skal det endnu være værre, og i Ribe skal mange huuse være gandske ødelagde af den høye flod og de med sig førende iismasser. Meget korn og høe er bedervet, da vandet gik høyt op i huusene, fleere kreaturer og mange faar ere omkomne. ...

$183919 / 2$. . Havde denne aften et lille gjestebud, da grev Sponneck og øvrige sessionsherrer beærede os med deres besøg. Men det utidige først at komme til bords $\mathrm{kl} .10^{1 / 2}$ var ikke tilsigende for os, og vi ville alle saa ulige behageligere have moeret os mellem os selv og ved forelæsning; dog er greven en meget behagelig mand, og skatter vi ham høyt for hans rettsindighed og drivtighed. .... .

$18399 / 3 \ldots$. Broder Hans tog formiddagen bort efter at have været hos os i 5 uger. Hans herværelse var hele tiden os til glæde, ligesom han lod til at have befunden sig vel hos os. Hvor er hans alderdom saa glad roelig og tilfreds $i$ hans sind; med sin stilling for den kommende tid bærer han ingen trykkende livets byrder og sorger, er endnu sund og rask og spores ey synderlig, at hans legems kræfter aftager, ligesom hans sielekræfter endnu have den fulde spænding. ...

1839 11/1. Stormen havde raset 8. og 9. jan.

1839 19/2. Grev Sponneck = stiftamtmand i Ribe grev M. S. W. Sponneck. 
$18397 / 6$. . Havde denne morgen det ubehagelige, at Hans kom til at rage sammen med den græmmelig sære Nicolay, og vi beklagede meget ey at have ladet Nic. reise i gaar, som hans forsæt var. Han og Joh. Andres blive alt mere vanskelig at omgaaes, ligesom alderen i det hele io giør vanskelig. Dog er broder Hans af alle vi brødre den, som er best at komme til rette med. ... .

$183910 / 6 \ldots$. . Broder Hans modtog brev fra Lichtenberg i Kiøbenhavn med ubehagelig efterrettning Michelsens handel angaaende, hvormed det seer mistrøstelig ud; ogsaa min kongl. koncession, hvilken ieg vilde have havd overdragen paa mine sønner, fik ieg uforandret tilbage, og sees det er ved saadanne ting det rigtige at lade alt gaae $i$ sin vante tuur. Her hiemme fra i Brede er det vanskelig at opnaa noget, da det er collegiernes princip at tage hiemmeøvrighedens erklæring til grundmaal ...

$183917 / 7 \ldots$. Vore 2de karle sloge i dag græs i Smedeng, som er meget got groet, aldrig i min tid var den saa god; ieg troer der bliver $20 \mathrm{l}$. høe; aaret før ieg fik den, blev der 7 læs - og den moye og bekostning, ieg har anvendt at faa vand over den lønnes rigelig. Den stod og sidste aar blank fra mortensdag til 1. may.

$193910 / 8$. . Brev fra .. . Emanuel \& Sohn . . a af meget bitter, ubehagelig indhold, der forsatte mig i daarlig humeur, og ieg kedes ved at korrespondere med dette huus, som har foraarsaget mig mere kummer end alle mine [andre] korrespondentere tilsammentagen. Disse jødemennisker erkiende lidt, hvor god og troe og redelig ieg fra første tiid af har meent det med dem, og ieg giorde vel imod mig selv, hvis ieg ophævede ald forbindelse med disse folk. ...

$183928 / 11$... Mine vakre brune reisehopper, kiøbt af A. Winther den 9de aug. 1827, bleve skudte i dag; skiøndt endnu

1839 10/6. Svogerens landhandel var året i forvejen blevet forbudt, og Hans W. havde gennem sine forbindelser i København søgt at få forbudet hævet. 
temmelig raske og got kunne æde deres foder, saa var især Lotte saare stiv, og det blev det villige dyr for besværlig, og ey kunde ieg nende at quæle dem. O! hvor gjorde det mig saa ondt at skille mig med disse troe og raske dyrer, hvis lige ieg vist aldrig faaer. De vil saa lidt som min gamle skimmel gaa mig af erindring, og stedse vil ieg mindes dem med taknemmelighed. Mange tusinde mile bragde de mig afsted, mange besværligheder og farligheder deelte de med mig og aldrig kededes de med og ved de længste dagsreiser . . . Pidsken vilde disse dyrer ikke vide af, og $i$ de sidste 9 aar førte ieg heller ingen med mig. Det var et par stærke lobere, og ieg fandt endnu aldrig nogen, som kunde kiøre mig forbi, naar ieg vilde lade dem tømmen frit. ...

$18398 / 12 \ldots$ Vor gode konge har forladt denne verden, sit kiere folk og er død den 3die december ... Begyndelsen af hans regieringstiid faldt i en saare ulykkelig periode. - Landet besatt af franske - krieg med England og tilsidst med alle continentalmagter, ved fredsslutningen gik Norge for Danmark forloren, og riiget leed derved et uoprettelig tab. Derover og ved daarlig bestyrelse kom finantserne $\mathrm{i}$ den største uorden, indtægterne formindskedes, udgivterne forøgedes, men kongens milde hierte tillod ikke, at paalægge sit folk nye skattebyrder; mand skrev ubetænksom bancosedler, uden fond, som naturlig ey kunde holde sig, ald tillid tabtes, bancosedler faldt til 1 a $1 / 2$ sk. pr. rdlr., de største urettfærdigheder fremkaldtes derved, den usalige rigsbankforordning fremstod og misnøye opvaktes derved i hele landet, men især $\mathrm{i}$ hertugdømmerne. Den gode konge forstod ey rett at vælge hans raadgivere og dem, som skulde styre landets vel, og hvem han engang havde tilvendt sin tillid, unddrog han samme sielden, vel aldrig, om der endog kunde være nok saa megen grund herfor. Han var meget uhældig i sit valg af de mænd, som skulde bestyre finantserne, især Møsting, og finantsbestyrelsen var saa daarlig som mueligt i mange aar, hvorved landets gield forøgedes, i stæden for at det i 25 fredsaar saa let kunde have ladet sig formindske. 
Omendskiøndt selv ikke kriger var Frederik d. 6te dog stoer ven af soldater, og dette var hans kiephest, der kostede landet saare meget, men alt har sin ufuldkommenhed, alt sin skyggeside her $i$ verden.

Den afdøde havde intet behagelig i sit udvortes, og saadant fortrædeligt vranten ansigt veed ieg fast aldrig at have seet, ogsaa ved samtale havde han intet mindre som tækkeligt. Men hans siel var god, og hvis det var gaaet efter hans onske, da var der end ikke funden en eneste ulykkelig $i$ hans land ...

$183917 / 12$... Hvilken ulykke ogsaa for vort land, om Chr. 8de for tiden skulde vorde os berøvet, ham som alles haab og tillid hælder sig til og haabentlig ogsaa vil svare til de forventninger, mand lover sig af ham. Paa en værdig maade er han fremtraadt, alle hands ord og handlinger vidne om forstand og villie, og Danmark kand under hans regiering see en bliid og lykkelig fremtiid imøde, derfor Gud velsigne og ophold os ham.

$183931 / 12$... Ellers herskede Gud skee lov fred i vor verdensdeel; kunst og videnskab blomstrer, og alt iler større fuldkommenned imøde, især dette med hensyn til befordringsvæsenet - mand reiser ikke mere, men flyver afsted paa dampvogne og dampskibe, hvilke bestandig tiltage og forøges, ligesom iernveye anlæg alt meer og meer finde sted.

Aaret var i det hele tagen, men især for vores land frugtbar og velsignet; priiserne paa alle landets produkter vare gode, men især var creature $i$ høy priis, en følge af de mange søerustninger, hvor der udfordredes saa meget for at proviantere de store flaader. Kornpriiserne vare efteraaret rug $8 \mathrm{mk}$, byg $6 \mathrm{mk}$. 8 , havre 5 , boghvede $5 \mathrm{mk}$.

Vi kiøbte dette aar megen uld, Wilhelm mange strømper, og gode udsigter aabnede sig for $\mathrm{knipl}$. handelen, da denne artikel nu bliver mere mode igien, men for uld og ulden bindetøy tegner det sig ikke got. De til Ney York og Philadelphia sendte

1839 8/12. Møsting = geheimestatsminister Johan Sigismund M., bl. a. overdirektør i rigsbanken og finansminister.

1839 17/12. W. har hørt, at Chr. 8. var syg. 
strømper henligger usolgte, saadan vil det vist ogsaa gaae andre speculanter $\mathrm{i}$ denne artikel, og da mand i Jylland ret har lagd flid paa at giøre varene saa lætte og ringe som mueligt, saa underligger denne artikel et stort fald, og sikker vil samme næste aar blive ligesaa vanskelig at faae solgt, som den dette aar var vanskelig at faae kiøbt. Clason i Hamburg, som har giort blæst af at kunde bruge alt bindetøy, hvad Jyl'land frembringer, indsmigret sig ved prinds, nu kong Christian, der har tilskreven adskillige $i$ landet at understøtte hans foretagender, - og bestilt en betydelig deel bindetøy hos prangerne, kommer vist tidlig nok og vil vist enten som ordløs mand komme til at staae til skamme, eller han maae underkaste sig betydelige tab.

Ferdinand bestemte sig dette aar for kniplingshandelen og gaar i compagnie med sin broder, hvilket og vil være den sikkerste vey for ham at fortiene sit brød i verden, thi det har sine stoere vanskeligheder til vore tider at entrere noget nyt, der ey har hiemme $i$ egnen; vore kniplinger derimod er et yndlingsarbeide $i$ denne egn. Denne handel er bequem og læt at drive. Vore mange connexioner lætter afsætningen, tillige gives for tiden kuns faae, der af nogen betydenhed driver denne handel, og disse faae ere tillige storste deelen gamle folk.

1840.

1840 10/2 ... Fuldendt og afsendt til grev Sponnek med mine tabeller, efter hvilke af uld er kiøbt

mærskuld 1839

103.578 pd. værdie 94.541 Rbdlr.

Jyllandsuld

54.085 pd. værdie 25.978 "

Told, prov. og kostninger

$6.816 ”$

Rbdlr. 101.357

eller crt. mk. 190,044 mk. Strømpe

39.367 for

19197 dossin,

Rbd. 140.724

1839 31/12 Clason, jvnfr. 1842 17/8 
eller crt. mk. 263.857 indført $i$ landet og udgiven for uld og strømper, sandelig en stoer resultat, og det største ieg nogensinde havde eller nogensinde faaer; hertil kommer endnu 7000 rbdlr. eller $13.125 \mathrm{mk}$. for kniplinger. Summa summarum $276.982 \mathrm{mk}$.

Af iydske strømper og andet bindetøj opgav ieg, at efter min overslag er kiøbt og udført 87587 dossin, værdi 194556 rbd. eller $364792 \mathrm{mk}$. De 4re strømpehandlere H. Lorenzen, Frey, Andresen og W. Nissen havde heraf kiøbt 60387 dossin, værdi $127891 \mathrm{rbd}$. eller $239795 \mathrm{mk}$. Hvem skulde vel have troet, at saa meget tilvirkes af denne artikel, som saa lidt er vorden paaagtet før? Ingen under at $i$ bindeegnen forbruges saa megen uld. For saa stor en sum er der vist heller aldrig bleven bunden og udført som dette aar, og skulde de americanske forsendelser ophøre, da vil afsadsen af denne artikel heller aldrig saadan vorde fremmet.

1840 21/2. . Skrev til grev Sponek i Ribe, Trøyburg kiøb ved godsets beboere angaaende, som ieg saa gierne vilde fremme. Gid ieg maatte opleve den glæde, at mit project iværksættes; ieg vilde ved at give den første impuls hertil kunde giøre mig fortient for de sildigste slægter, men det vil vel sagt have sine store vanskeligheder at faae saa mange deltagere enede.

1840 24/2. . . Grev Sponek beærede mig denne eftermiddag med hans besøg, fortalte at have giort en reise til Friederitz for at tale med kronprindsen om, at han vilde forvende sig hos dronningen for at modtage kniplingerne.

1840 26/2. . . Havde denne aften [besøg af] sessionsherrerne. - - Grev Sponnek var særdeles artig. Ja! mand kunde sige fortroelig venskabelig, og det er en meget interessant mand.

1840 28/2. .. I dag blev endelig takken bragd af det stoere mønster med dronningens navnetræk C. A., der har circa 400 stokke, er 8 tommer breed og vel det største mønster, som her nogensinde er giort af denne slags og gammeldags undtagen. 
Jeg troer, at tegningen er lykkedes got, og at Hochberg vil kunde indlægge sig ære dermed. Sendte takken til Ribe for at indhente grevindens dom herover...

1840 6/3. .. Wilhelm var i Tønder og fandt efter bestemmelse her $\mathrm{H}$. Lorensen, Frey og Chr. Andresen, som efter mange betænkeligheder enedes om at gaae ind $\mathrm{i}$ min plan og for egen regning giøre forsendelser til America. At ieg vilde itage en actie med var ene det, der bevægede dem til at vove noget ved directe forsendelser, da de tosser hellere krediterer en stodder $1000 \mathrm{dlr}$. $\mathrm{i}$ Hamburg end at anbetroe et sikkert huus der 100 dlr. i commission. Jeg haaber, som Gud vilde give, at det vil være et gavnlig foretagende, sikkre de 4re strømpehandlere deres handel, giøre dem mere uafhængig af hamborgerne, vedligeholde de saa uundværlige forsendelser til America og derved gavne det almindelige, vedlige- og opretholde denne for vort land saa gavnlige industrie.

$184014 / 3 \ldots$. Var eftermiddagen i Bredekroe inscriptionen paa sølvtøyet til vor gode præst angaaende. Jeg bragde her stevningen i aaen paa bane, hvor der nu er tinget saa længe, om ved 30 aar, men kommer ikke videre dermed. Det blev besluttet, at herredsfogden skulde foranstalte et møde, hvor dette saa gavnlige anliggende da skulde ordnes og ved contract lov.lig bestemmes ....

1840 20/3 .. . Skrev til kronprindsen Frederik Carl Christian $i$ anledning af det $i$ arbeide havende stk. knipl. til dronningen, hvilket blev sendt til den mig saa bevaagne grev Sponnek, der vil anbefale samme.

$184023 / 3$.. Maatte $i$ dag sidde en times tiid for maler Kier, som vil portraitere mig og min kone.")

$184020 / 6$. . . Skade at det ey i dag var smukkere veyr til den gode pastor Lauthrups iubilæum. Det manglede imidlertid

1840 23/3. $184025 / 3$ oplyser W., at hans hustru tidligere er malet to gange. Ingen af billederne er dog særligt vellignende.

Kier = ikke nævnt i Weilbachs kunstnerleksikon. 
ey paa tilhørere, og kirken var overfyldt af mennisker, sandsynligvis var det første gang en slig festlighed i vores kirke fandt sted. Handlingen var $i$ det hele ophævende og rørende, den største roelighed og opmærksomhed fandt sted, rørt var alle hierter og alle takkede og velsignede den værdige olding. Der var music i kirken, min broder holdt først en lille bøn og tale for alteret, siden besteg oldingen prækestoelen og holdte en hiertelig tale - foredragen med' ungdommelig kraft. For alteret talte siden provsten og overrakte en pragtbibel, som geistligheden gav, siden traadte amtmand Tillisch frem, holdt en meget smuk og hjertelig tale for sig selv, siden talte han $i$ kongens navn og beprydede ham med dannebrog ridderkors. - Ved denne handling og amtmandens ord viiste sig oldingen meest rørt, han viiste forresten en sielden fattelse og en sielden kraft.

I kirken var sit billede, malet af Kier, opstillet. Hiemme biev et sølv skrivetøy, en gave af sognet, ham overrakt, samt andre smaae foræringer af andre, blandt andet 2de kobberstik. Dora gav af hendes haandarbeide en calender.

1840 4/8 [Åbenrå] . . . E Efter middagen toge vi sambtligen til Farvemølle og tilbage til Apenrade. Her var stoer stads og allarm, thi kongen og dronningen med et stoer følge kom denne aften eller nat til byen, hvor i fast alle gader var ilumineret, æresporte opreiste o. s. v. Det smukkeste veyr begunstigede disse festligheder, og der var en vrimmel af mennesker, saa mand neppe kunde passere gaderne. Vi kom først til Riis kl. $21 / 2$, da dagen alt gryede.

$184016 / 10$... I Aarhuus avis læste ieg et krænkende inserat fra den fatale Dalgas imod min ældste broder angaaende tænkestøtten for vor afdøde konge, hvilket sikker for min broder vil være ærgerlig at læse - men hvad vilde han ogsaa blande sig heri? Mand see, at Dalgas har attraaet meer at sætte sig selv som kongen et minde, cg at forfængelighed var det, som ledede ham; ellers vilde han istæden for at ærgres have 
glædet sig til at mænd som min broder og justitsraad With antoge sig og fremmede en sag, der uden deres medvirkning neppe var bleven udfert og ved disse smaalige kievlerier nu mueligen ogsaa standses; at det sidste meget ville glæde Dalgas, derom kand mand holde sig fast overbeviist. - -

$184018 / 10$.. . Ferdinand med Anthon toge til Medolden, hvor den sværmeriske pastor Hass holdt sin afskedsprædiken; han nedlægger sit embede, [vil] være missionær og vil som det heder reise til Palästina for der at præke omvendelse. Den stakkels mand mener det vist got, gid det gaae ham vel og gid han see frugter af sine bestræbelser, af det stoere offer, som han bringer hans forskruede ansigter. - -

$18407 / 12 \ldots$. Skrev til dronningen med de til hende forarbeidede kniplinger, hvilke Ferdinand skulde overbringe. Hochberg havde atter travel at faae det lille digt prentet, der følger samme; han har arbeidet herpaa dag og aften fast uafladelig i 5 dage, men det er ogsaa meget smukt, og vil haabentlig finde biefald. Skrev til grev Sponek med afskrivt af digtet og mit brev til dronningen; det lille digt forfattet af Christiane — lidt forandret ved hendes fader og lyder [i uddrag] saaledes:
Lidet kuns vi bringe kand til veie dagligt brod os giver dog vor flid. Naar vi kuns benytte ret vor tid, nøysomt sind er livets bedste eie.
Held vor egn, at denne næringskilde selv for svage knipler aabnet er, som for os saa skiønne frugter bær, naar vi tiden ey for unyttig spilde.

1440 16/10. Dalgas = kammerråd, landøkonomisk forfatter C. Dalgas, Aldebertsminde ved Vejle. -

With $=$ herredsfoged, stænderdeputeret J. P. With. Angående denne sag, se iøvrigt: Århus Stiftstidende 7/9, 14/9, 28/9 og 9/10 1840 .

1840 18/10. Pastor Ludv. Daniel Hass var missionær i Smyrna til 1847, derefter sognepræst i Hals og Nibe, folketingsmand og landstingsmand, iфvrigt grundtvigianer, derfor Wulffs modvilje overfor ham. 
Vil vor dronning prøven huld modtage, da vil glæde lue i vort bryst; troe erindring om hin høye lyst blid belyse vil vor fremtids dage.

Gid nu vor gave maa finde blid modtagelse og gid dette have til følge, at vore kniplinger af dronningen og hoffet vorde mere paaagtet. Da vilde dette kunde have heldbringende følger for denne industrie og for vore kniplerinder.

1840 24/12 ... Ved Ferdinands hiemkomst fra Kiøbenhavn blev vor juleaftensglæde meget ophøyet. Han var bleven meget naadig optaget hos dronningen og vore kniplinger havde funden hendes biefald. - Han medbragde fra dronningen en kostbar gulddaase - 20 spec. gratification til de 2de kniplerinder og et brev fra dronningen med bestilling af en fuldstændig garnitur kniplinger til vores tilkommende kronprindsesse. - Ferdinand fandt megen understottelse ved hans hverv af grev Sponneks søn, kammerjunker Sponnek - blev opfordret til at besøge etatsraad Garlieb - det vigtigste medlem af commercekollegiet, med hvilken han underholdt sig 2 timer, samt cammerherre Louzow, hvor han og samtalte længe. I det hele har han spillet sin rolle got og sikker overalt vunden biefald.

$184025 / 12$.. . Skrev fast den gandske dag paa min betænkning over huserehandelen, der endelig nu er reenskreven, samt til grev Sponnek. - -

$184031 / 12 \ldots$. Vi havde et frugtbar og velsignet aar; høsten blev vanskelig, dog kom omsider alt $\mathrm{i}$ huus og for det meste ubedærvet. - Det var et fortrinlig aar for landmanden, han havde meget at sælge og alt blev got betalt. Prisen var ved aarets ende: Rug $7 \mathrm{mk}$, byg $5 \mathrm{mk}$. $8 \mathrm{~s}$. á $6 \mathrm{mk}$, havre 3

1840 24/12 .. . Garlieb = Gotfried Garlieb, deputeret og departementschef for generaltoldkammer- og kommercekollegiets 3. sektion.

Louzow $=$ Frederik Lowzow, direkt $\varnothing \mathbf{r}$ i generaltoldkammer- og kommercekollegiet. 
mk. 8 á $4 \mathrm{mk}$., boghvede 5 á $5 \mathrm{mk}$. $8 \mathrm{~s}$. Kreaturer vare overvettes dyre, og en god maver stud blev betalt med 40 til 50 rdlr., hæstene ogsaa dyre, svin, faar etc. ligesaa; smør, talg, uld, huder og skind, kiød og flesk alt var dyre, og bondens velstand forøgedes betydelig dette aar....

I vort lille land blev den liberale aand mere levende, folket vækket af dets lange slummer, og folk og stænder frembragde deres ønske for tronen, at en mere frie statsindrettning maatte finde sted. ....

Med hensyn til handel var uldhandelen om ogsaa ey saa vigtig som forrige aar, dog ikke ubetydelig, kuns har ieg den Klixbøll uld, $3000 \mathbb{H}$, paa halsen endnu, og der bliver mange penge tabt paa mærskuld $i$ aar. Diquie, min største fiende $i$ denne brance, fik nok af det og rømmer feldtet.

Strømpehandelen blev daarlig, de americanske forsendelser hørte op og det ser ringe ud med denne artikel. Disværre har jeg andeel $\mathrm{i}$ forsendelser til New York, hvor der sikker vil tabes meget ved.

Kniplingshandelen var $i$ optagelse og mine sønner drive samme med lyst og $\bmod \ldots$.

\section{1.}

1841 26/1 . . L Læste i Alton. Mercur en lille opsats over vores knipl. til dronningen, der overalt vækker opmærksomhed og bringer vor knipl. fabrik i stoer renomé.

$184127 / 1$. . Sognefogden Dethlef Lassen i Braderup blev valgt som deputeret, iustitiarius Hansen i Lek suppleant. Det lod til, at mand interesserer sig mere for vort stænderværk, og at mand forfares med mere umsigt og betænksomhed, skiøndt deres tal var mange, der ey indfandt sig; ieg gav min stemme Lorenzen paa Wassersleben ved Flensburg og Dethl. Lassen som suppleant, tog aftenen hiem, hvor mine beretninger angaa-

1841 26/1. Alton. Mercur, udbredt avis i hertugdømmerne. 
€nde vore kniplingers offentlighed vakte glæde. Hørte at broder Hans ey i gaar var bleven valgt i Døstrup, men Holm og Gram havde der de fleste stemmer. Nu kommer min broder nok ikke med tiere, hvilket giør mig ondt, især da han saa fortrinlig. egner sig til at tolke folkets sag og saavel har forstand som villie at udfylde sin post, men han er io gammel.

$184112 / 2 \ldots$. Brev fra $H$. Wulff med endelig bestemt efterretning, at han er valgt i Ribe, medhen ogsaa i denne distrikt, som deputeret, og at han har antaget valget. Tillige har han fáaet indbydelse til at blive medlem af et lært selskab, og han bliir paa hans gamle dage æret fra alle kanter. $-O$, hvor er det dog rart at boe $i$ et land, hvor der ved udmærkelser €y tages hensyn til stand og byrd, men til fortienesten, til ævne og villie, og hvor er det got tillige, at i samme land allene loven er den herskende magt - derfor, lovet være Gud, at Danmark blev mit fødeland.

1841 18/3 ... Skrev til grev Sponnek i Kiøbenhavn angaaende knipl. og uldgods. Knipl. opgav at have tilvunden egnen i de forrige tider circa $100.000 \mathrm{dlr}$. crt., nu circa 50.000, material 10 p. c. Bindetøy blev før fortient paa $1 \mathrm{~W}$ uld i arbeidsløn 4 til $6 \mathrm{~s}$., i den senere tid 12 til $14 \mathrm{~s}$, eller saa meget som et pund uld koster.

$184124 / 3 \ldots$. Var for sidste gang dette foraar med hensyn til arbeide paa Reispold og kom med min spade ret træt hiem. $\mathrm{Nu}$ ere mine vandledninger saa udstrakte, som de kand blive. Smedeng staar gandske blank, og vandet risler i mengde over en deel af Reispold. Mit arbeide vil sikkert ikke være forgieves,

1841 27/1. Justitiar Andreas Hansen, sen. stænderdep. og amtmand over T $\phi$ nder amt under opr $\phi r s r e g e r i n g e n$.

Lorenzen $=$ Joh. Sybrand L., godsejer og ejer af kobberm $\phi$ llen ved Flensborg.

Holm = landmåler Samuel Holm, Møgeltønder, der ved valget i 22. valgdistrikt fik 96 stemmer, medens Hans Wulff fik 106.

Gram = sognepræst i Daler Caspar Frederik Gram. 
men bære gode frugter, som tiden nok vil vise. Der er heller ingen her i egnen, der giør sig saa megen umage og, ieg tør sige, handler saa betænksom ved og med vandledning som ieg.

$184131 / 3$. . . Det var i dag 1784, altsaa for 57 aar siden, at pastor Lautrup i Tinglef som student holdt sin første tale. Hvor har han præket ofte, lært og gavnet, opbygt og trøstet saa meget i denne lange række af aar, og endnu er han rask, giver haab at kunde virke til velsignelse en tiid lang endnu, hvilket Gud vil give.

$18412 / 4 \ldots$. . Brev fra Quedens i Ribe. Han kand ikke bruge de ham tilbudne vexler, Radoor ikke heller, og nu kommer mand ordentlig i forlegenhed med sine contanter. Tydelig sporres, at der er penge nok mellem, folk og velstand i vort lykkelige land.

$18413 / 4$. . Prikbrevet til det stoere mønster blev endelig færdig i dag, hvilket rett har satt Hochbergs udholdenhed samt kunstflid paa prøve. Gid det nu kuns maae svare til hans forventning.

$18418 / 5$. . kreemarkenet [i Tønder] var daarlig, og kreaturene har faaet et uhyre fald .....

$18414 / 6$. . Ferdinand tilstillede mig et saare bitter, ubehagelig brev fra den smaaelig egennyttige broder Hans, der med de stoere offre, ieg i en række af næsten 50 aar har bragd ham, endnu ey er tilfreds, men har giort sig haab, at ieg skulde opofre alt. Hvor sørgelig, at havesyge skal sønderrive et baand, der $\mathbf{i}$ saa mange aar kiedede os til hinanden, at vi i vore sidste dage skal blive os fremmed. En god villie at efterkomme, hvad der var sin pligt, ville have tilfredsstillet mig; saa synlig mangel paa samme foranledigede, at ieg maaske for dierv sagde ham sandheden, men slige sandheder finder ingen anklang i Jylland, hvor mand fast affinder sig med snak, og dette har fiernet os fra hinanden.

$18418 / 8 \ldots$ Fuldendt mit fatale skriverie til broder Hans.

1841 2/4. Radoor $=$ købmand Friedr. Julius R. i Tønder. 
Gid ieg havde dette smaaelige krammerie af hovedet; hvor var det dog en uheldig tanke at skrive og sende mig en Ratzenschnurre, der tolkede sine forkerte og usande anskuelser med hensyn til mit tilgodehavende. Egennytte forenet med det ønske at forhøye sine døttres arv har meget vildledet ham, dog veed ieg meget got, det ey er slet meent. Han er allene gaaet ud fra den anskuelse, det kom saa nøye ey an med mig, da ieg alletider har ladet mig saa meget befalde; men alt har sin grendser.

Overlod ved slutningen ham at betale, hvad han vil ... .

$18418 / 10$. . Fuldendt mit brev til broder præst og udtalte mig efter min overbeviisning over vort giensidige forhold hidindtil. Vil han samt den ældre broder nu ey høre og paaagte, hvad sandt og rette er, saa lad dem gøre, hvad de vil, ieg troer at have giort mit. ...

$184125 / 10$. . Fuldendt afskrivten af mit fatale [brev] til Hans Wulff, og er det mit forsæt ikke tiere at skrive til ham, det være, da vi kommer paa venskabelig fod med hinanden igien. ...

$184131 / 10 \ldots$ Oct. var en regnmaaned, og vi havde kuns 9 regnfrie dage, en sørgelig maaned for høst og sæd. I mærsken seer det sørgelig ud, der staaer endnu en stoer deel havre ude, vist totalt bedærvet. Sæden blev ringe lagd og paa øerne kuns $1 / 3$ af, hvad der skulde have været saaet.

$184123 / 11$. . Fuldendt reenskreven mit brev til H. Wulff og tog afskeed med ham; thi ikke længer vil ieg bryde mit gamle hoved, ærgre mig og som hidtil forsømme mine ting over noget, der dog aldrig faar ende, da han ingen grunde, ingen raison tager imod, men kuns altid bliver ved at besmykke sin sag, saa meget han ogsaa modsiger og blotter sig, kuns giver snak $\mathrm{i}$ stæden for beviis.

1841 8/8. Ratzenschnurre $=$ krønike, løgnehistorie.

$184131 / 10$. Øerne er formentl. de nordfrisiske фer. 
... Nu! han er gammel, gamle folk sære, og dette undskylde ham. Himlen give, at hans sidste dage ey maae blive kummerfulde, og at dette brud ey for meget maatte krænke ham. Mit brev dateret 16., sluttet den 23. ds.

$184129 / 12$. . Gav mine sønner en fortient irettesættelse, at de hele ugen ey havde været i Bredebroe, ikke kymrede sig om kniplingshandelen, der stedse burde ligge dem paa sind og hierte og lader deres tante sidde ene, ofte raadvild, hvor de havde tid og leilighed nok til at paaagte, hvad fornøden er og hver dag lobe omkring i marken for at spadsere. - I bogen fandt ieg ikke engang forrige uge efterset og afsluttet. - Min irættelse, der vel var drøy og skarp, blev ilde optagne, og Hochberg opponerede paa en usømmelig maade ...

$184131 / 12 \ldots$ Kunst og videnskab fremmedes ogsaa dette aar; meer og mere faaer mennesket elementerne i sin magt, der maae tiene ham som herre, og underfuld er det, der frembringes ved damp. Jernbaner giør stærke fremskridt, og snart vil der udspinde sig et net giennem hele Europa, saa mand i et nu vil kunde forsætte sig fra den ene ende til den anden, fra Moskou til London fra Hamburg til Triest. Kuns i vort danske land vil det ingen fremgang faa. Der bliver projekteret nok, men intet kommer til udførelse.

Med hensyn til frugtbarhed hørte aaret 1841 ey til de velsignede, liden varme, megen regn. Høsten blev især ugunstig, vi havde uophørlig regn; meget korn blev bedærvet og staaer til deels ude endnu. Diette var især i mærsken tilfælde, hvor der endnu skal staae megen korn, havre, byg og bønner i marken og raadner. Priiserne vare temmelig høye: Rug $11 \mathrm{mk}$., byg $7 \mathrm{mk}$., havre 5 og boghvede $10 \mathrm{mk}$.

Vi vare hældig med vores korn, der kom alt got i huus, hvilket fast overalt var tilfælde i denne egn.

Kreature fik et stoer fald, og de handlende tabte mange penge dette aar.

Hvad vores handel angaaer, gik samme saa temmelig. Der 
blev i det hele kiøbt circa $100.000 \leftrightarrow$ mærsk- og $50.000 \mathbb{H}$ iydsk uld. For kniplinger blev der udgiven

*), men i det he'e blev der ikke meget fortient ....

\section{2.}

$184219 / 2 \ldots$ I aftes brev fra Christiane Jessen med den efterretning, at hendes mand $\mathrm{i}$ forgaars blev udløst af dette livs ham trykkende baand, sine legems og siele lidelser endte. Vel ham, at det baand, der fengslede ham til dette liv blev løst. Han har i mange aar været meget svag, og hans eneste glæde var sin vakkre kone, der saa got forstod at trøste og opmuntre ham, saa troelig deelte hans lidelser og derfor nu ogsaa med roe og glæde kand tænke og erindre sig den hedengangne. Hun tager nu til hendes hiem, til sin gamle fader igien og vil haabentlig her kunde forleve gladere dage.

$184230 / 4 \ldots$. I familiehenseende giorde Hochbergs reise til Holland, Belgien og Frankrige denne maaned tænkelig, ligesom det for mig var interessant at kunde celibrere mit handelsiubelæum i Hamburg og Altona, hvorhen ieg ved paasketid 1792 antraadte min første handelsreise og der ene og forladt ankom ...

$184227 / 6$... Ved Ribe og i omegnen seer det sørgelig ud. Floden har været høyt oppe og er det endnu, engene staar blanke, hvad der var huggen er dreven bort, saare megen havre staaer $i$ vand og denne egn lider et stort tab, hvilket vist ogsaa saavel synder som nør paa vil være tilfældet. - - -

1842 10/8 . . Tog med Ferdin. og Wilhelm, der rejser til [Hamburg], til Tonder, hvor ieg paa amthuuset foreviste de efter dronningens ordre for kronprindsessen forfærdigede knipl.:, der fandt udeelt biefald, og hvor ieg fandt en smigrende modtagelse, ogsaa af amtmanden gientagen opfordret til at forevise denne

-) tallet mangler.

1842 19/2. Christiane Jessen, født Lautrup, »digterinden Anna «, gift $1^{0}$ med sognepræst Jørgen Simon Jessen, jvnfr. Sdj. årb. 1893, s. 197 og P. Feddersen Jensen: Visby sognekrønike, 1946, s. $67 \mathrm{ff}$. 
garnitur [for] kongen, der nærværende tid er paa Føhr. Ogsaa amtsforvalter Fischer med familie glædede sig til at see disse smukke knipl[inger], og det var mig meget kiert at have foreviist samme ....

$184216 / 8$ [Før] ... Toge bort fra Dagebøll kl. 10. Vinden blev dødstille, og vi satte os paa en baad, der kom til os og roede til Wyck, vore sager maatte vi lade blive tilbage. Færgeskibet saa vi herefter sidde fast paa en sandrevl og glædede os til at være kommen derfra .... Her er en stoer conflux denne tid og mange fremmede, der fortærer mange penge, saa det rett er en hældig tid for Wyks beboere.

$184217 / 8$ [Før] ... Denne dag var een af de interessanteste for mit liv og vil stedse blive mig uforglemmelig. - I anledning af at foreviise den efter dronningens ordre forfærdigede garnitur kniplinger, hvortil ieg af kammerhr. Krog var bleven opfordret, havde ieg denne eftermiddag audience hos kongen. Kammerhr. Krog sagde mig denne morgen, at kongen viste ieg var her, at ieg slett ikke behøvede at melde mig til hoffmarskallen, men blot indfinde mig kl. $4^{1 / 2} \mathrm{i}$ audience gemakket, hvor ieg da vilde uden videre faae audience. - Ieg giorde, som han sagde og dette om saa hellere, da min daarlige fod efter muelighed skulle skaanes for støvler. - Saa gierne ville ieg have hilst vor forrige Apenrader amtmand, nu kongens kabinetssecretair, kammerherre Tillisch, der staaer hos mig og alle, der veed at skatte hands værd, i kier erindring, men ieg ville ikke bemøye og forstyrre ham, da han har saa saare meget at bestille. - Da han vilde stige paa vognen for at kiøre til badestedet, gik ieg i mine tøfler hen til vognen og hilste ham. — „De her!“ raabte han mig imøde, bydende mig venlig haanden, „og har ikke besøgd mig? Dette giør mig ondt!“ Med faae ord sagde ieg ham mit ærende.

1842 16/8. Conflux $=$ Sammenstimling.

1842 17/8. Kammerherre Krog = amtmand over Tønder amt Friedr. Chr. v. Krogh. 
„Disse kniplinger maae ieg see,“ sagde han. „Naar ieg kommer fra badet, besøger ieg Dem, hvor logerer De?".

Efter hans bortreise sagde mig senator Rehder fra Husum, en meget artig mand, ieg maatte giøre hoffmarschallen min opvartning, som han ogsaa havde sagd mig før, thi saa blev ieg inviteret til taffels —, men ieg betakkede mig for denne ære, der med hensyn til min daarlige fod, der ikke taale støvlen, kunne være kommen mig dyre at staae. - Kammerherre Tillisch holdt ord, kom til mig, besaae kniplingerne, der fandt hans fulde bifald. - Ieg meddeelte ham nu, hvad ieg med hensyn til vores industrie havde at foredrage kongen, men beklagede, at en sædvanlig audience paa nogle minutter ikke ville være tilstrækkelig for at siige, hvad der laae mig paa hiertet. Den vakkre mand, der saa gierne fremmer alt, hvad der tiener det almindelige til gavn, billigede alt, hvad ieg havde at foredrage og sagde: „Det vil ieg see at faae anderledes; giør Dem færdig, ieg gaar til kongen."

Efter kort forløb kom han igien, bød mig at følge med og uden ald forberedelse, dog ogsaa uden ængstlig forlegenhed, traadte ieg frem for hans majestæt og foreviste den stadselige pynt.

Kongen hilste mig naadig og venlig, besaa de smukke knipl. og fornøyede sig til, at vort land kunde frembringe sligt.

Kuns Tillisch og hofmarschallen, kammerherre von Levezau, en meget fiin hofmand, vare tilstede, sidste fandt adskilligt, især kragen meget smukt. Da den 1/2 alen brede garniture kom for, spurgte den fiine herre, hvor meget en alen af disse knipl. vel kunde koste. Noget ubetænksom svarede ieg: Saa hen til 20 spec. Nu! sagde han saa, let henkastet - slige knipl. kiøber mand (mig syntes han sagde $i$ Mongs) for 5 spec. Denne bemerkning var for mig saare krænkende, som den var usand og uretfærdig, og ieg følede han ville hevne sig, fordi ieg ikke hav-

1842 17/8. v. Levezau $=$ sen. overhofmarskal J. G. Levetzau. 
de giort ham min opvartning og henvendt mig til ham. Kongen derimod sagde. Nu! ieg finder dog disse knipl. smukke.

Ieg foreviiste nu det nye pergament, Hochberg havde bragd med fra Belgien samt et brev af vort gamle til sammenligning, ligeledes en gammel takke af bullmünsteret i sammenligning med en nye efter Hochbergs methode. - Derpaa fremstillede ieg det mangelfulde $i$ vor industrie, og hvor nødvendig det var, saavel med hensyn til arbeide som münstre at holde skridt med tiden, og at det var nødvendig, der blev indrettet kniplingsskoler, som mand har i Belgien, Frankrige og Sachsen. - Kongen gik ikke saa nøye ind $i$ tingen, som ieg havde ventet og haabet, men tillod at ieg maatte komme ind med forslag, tilføyende, at hvad ieg havde at meddele med hensyn til det industrielle dermed at fremkomme.

For ved exempel at viise, hvorledes et industriegreen kand ruineres ved at levere daarlig arbeide, fremlagde ieg min indberettning fra 1839 med hensyn til strompehandelen. Kongen blev Clasons navn vaer, spurgte efter hans fabriksanlæg. - Ieg kom her noget i disput med hoffmarschallen, der ville henlægge ald skyld, at vort bindetøy ikke mere bliver søgd i Nøramerica, til den stoere pengemangel, der hersker der, og ieg mærkede tydelig, at han var den vindige Clasons protector.

Ieg adspurgte kongen, hvorlænge dronningen endnu agtede at opholde sig paa Sorgenfrie - han svarede til denne maaneds udgang, tilføyende, ieg vil skrive [til] dronningen, at hendes kniplinger nu ere færdige, og at ieg har seet samme.

Ieg havde det indfald at overrække hans majestæt et exemplar af min Blocksberger romance, der mueligt kunde moere ham, og efter at have forespurgt hos Tillisch i forveyen tildristede ieg mig hertil — sigende:

Ieg ved ikke, om ieg tør tildriste mig at overrække Deres

$184217 / 8$. Clason, se $183931 / 12$, Clason, hamborgsk købmand, Wulffs konkurrent. Blocksberger romance se: Indledn., s. 73. 
Majestæt en ubetydelig ting, men ieg veed, De ønske at see alle Deres undersaatter lykkelige. - Een af de lykkeligste staae for Dem, min lykke har ieg for en stoer deel Harzbiergene og navnlig Blocksbierg at takke for. Denne lille sang, indført i Blocksbierger bogen, er ikke digt, den indeholder historisk sandhed. Kongen svarede, det glæder mig, at De er lykkelig, ieg takker Dem, og tog venlig min viise.

Ieg frembragde nu min tak og gik. Audiencen varede omtrent en halv time. Gud veed, hvordan ieg er kommen fra det, thi ieg chenerede mig ikke i mindste maade, og om ieg ikke har kiedet kongen. Noget usædvanlig maae det imidlertid have været ham at see en underdan for sig, der med hensyn til sig selv intet ønskede eller udbad sig - derimod ligefrem yttrede — Deres Majestæt! — ieg er lykkelig.

Hoffmarschallen har sandsynlig giordt glosser over mig, da ieg ikke kiendte, som ikke beagtede etiketten, derimod haaber ieg, at min ugenerede holdning vandt $i$ det hele tagen kabinetssecretairens biefald. - Ieg gik med ham til sin boelig, her var han tør ieg siige venskabelig, bebreidede mig atter, at ieg ej strax havde besøget ham, og at det vilde fortryde ham, hvis ieg, kunde troe, at han glemte gamle bekiendte. Han sagde, at hvad ieg havde at andrage hos kongen med hensyn til industrie, skulle ieg kuns sende lige til ham, ligesom alt øvrige, der maatte ligge mig paa hiertet. - Derved er denne herre, der beklæder saa høy en post saa gandske ligefrem og den samme endnu, hvad han som amtmand var, ingen stolthed, men alt præg af godmodighed. - Han requiererede tilsidst et exemplar af min Blocksberg sang.

Ieg var da nu Gud skee lov færdig. - Da den sædvanlige audience time var der,kom kammerherre Krog for at paaminde mig. Han studsede ved at høre, ieg var færdig og havde allerede havd audience. Det lod til, at det ikke var ham kiert, ieg allerede havde henvendt mig til cabinetssecretairen og ogsaa han, scm hoffmarschallen, blev ialous. Enhver ville have æren og hos 
kongen insinuere sig. - Saa seer ieg da her ved denne ringe ting, hvordan det gaar til ved hofferne, og at de mange cabaler, mand læser om, kand være grundede. O, hvor lykkelig, at mand kand være uden for sligt, og at mand kand gaae den simple naturlige vey.

Det opvakte imidlertid megen opmærksomhed og stoer opsigt - at ieg, een saa ubetydelig mand, blev besøgd af forskiellige kammerherrer, og at ieg havde en saa lang privat audience hos kongen. - Alt hattede for mig og fast enhver kom mig med stoer opmærksomhed imøde. Dette var især tilfælde med mine medlogerende: Senator Rehder fra Husum samt brødrene amtsforvalter og doct. Dierks.

Da Dora nok onskede at blive her for at bivaane maskerade og assambler denne aften, Rehder og hans døttre saa meget onskede dette, saa gav ieg gierne mit minde hertil og tog ene bort med færgen til Dagebüll.

Dette var en lang psalme for $\mathrm{i}$ dag, maaske mine efterkommere til sin tid læser med interesse forestaaende og for mueligt i sin tid at komme min hukommelse til hjælp.

$184211 / 9$. . [Brev] fra vor gode Ferdinand ... Knipl. har funden hendes majest.'s biefald, hvilket bevidnedes derved, at hun lod tilstille Ferdinand en kostbar brystnaal med diamanter, hvis værd blev taxeret af en iuveler til rigelig $400 \mathrm{mk}$. og Hochbergs flid og møye ved dette vanskelige arbeide har altsaa funden den fortiente annerkiendelse ... Alles glæde var stoer endelig at høre noget fra Ferdinand og især at høre, det var gaaet ham saa godt hos dronningen, der til sluttning sagde, hun ville engang besøge os.

$184224 / 10$... Smukt . . . veyr, der passede os got til vort arbeide paa Reisspold, hvor ieg fik mit projecterede arbeide ud-

$184217 / 8$. insinuere $\operatorname{sig}=$ indsmigre sig.

Brødrene Dierks = amtsforvalter Boj Dircks, Løgumkloster, og læge Peter Dircks, Tønder. 
ført, vandledningen over det høye fordybet og bredere giort, men iorden afbenyttet til at sætte en dygtig demning, som nu forhindrer, at vandet ikke, før det maae, løber til aaen, den forhen hveentue plet nu kand holdes under vand og nu ey meer som før kand løbe over de smaae demninger. Vi kiorte 60 læs og leg kom aftenen uden at have spiist den gandske dag meget træt hiem. ... .

$184231 / 10 \ldots$. Oct. var $i$ det hele en meget god og behagelig maaned, meget gunstig for landmanden at faae sæden lagd, mærgel kiort og mangt arbeide beskikket. Ogsaa ieg afbenyttede den beleilige tid, flyttede i min lave moese, der i flere aar denne aarstid ey var tilgiengelig, hen til 1000 læs iord, der vil være et gavnlig arbeide for mig og mine efterkommere for den kommende tid og give denne før saa daarlige iordplæt, der gav en ussel afgrøde, en forhøyet værdie. $\mathrm{Nu}$ er ieg ogsaa med mine forbedringer meest færdig her. ...

$18426 / 11$... Skrev til . . . H. C. Henningsen i Flensburg med $100 \mathrm{mk}$. til understøttelse af den ulykkelig trængende cancellerieraad Holsts datter, hvorover Brasen har at forføye, og som er et samlet bidrag.

Gud, hvor det dog gaae op og ned i verden. Hendes fader eier af Trøyburg, en riig mand, der herskede som en fyrste, drømte vist ikke om, at hans datter skulde komme til at tigge. Hendes mand Thorstraten, eier af det betydelige kobberværk i Crusaa har faaet over 100.000 rdlr. fra Trøyburg, men alt er borte. Han i hospitalet i Flensburg og hun maae paa hendes sidste tid lide hunger og kummer. ...

1842 24/11 [Hamburg] ... Tog med Dora til Bergedorff, og

$184231 / 10$. 8/11 1842 afsluttes arbejdet i mosen; ialt er der udkørt 1100 las jord på plфjelandet der.

$18426 / 11$. Brasen $=$ herredsfoged i L $\phi$ hrd. m. m. Ferdinand Br. i Harres. - Thor Straten: Kancelliråd Bendix Holsts datter Marie var gift med Josias Thor Straten, der 1839 måtte gå fra kobbermøllen som en ruineret mand. 
ieg kiorte første gang i mit liv paa en iernbane; i mindre end $1 / 2 \mathrm{t}$. tilbageligges denne veystrekning af over $2 \mathrm{mill}$, og mand kommer veyen over uden selv at vide det $\mathrm{i}$ den tæt lukkede, smukke vogn. ...

$184231 / 12 \ldots$. Skrev nogle bemærkninger paa opgivelse af knipl. fabrikation i afvigte aar: 500 arbeiderinder 8000 rbdlr., traad 600 rbdlr. ...

Et aar er da nu atter endt og lovet være Gud, der ogsaa i dette aar lod saa meget got falde i vor lod, gav os sundhed og velsignede vor flid.

Knipl. handelen var ringe dette aar, og udsigterne ere morke for den kommende tid, thi de eftergiorde knipl. true vore ægte med undergang. Der maatte disværre skarres betydelig, mange fravende sig herover denne beskieftigelse, da de stakke's kniplingspiger finde saa ringe løn for dyre flid og møye. Kræmmeren kiøbe uden at vide, hvor [han] skal hen med varene, og alt er modløst og bekymret.

Vores Hochberg giorde foraaret en reise til Belgien, Frankrige etc. for at varetage fabricationen og efter muelighed forfuldkcmne vores. Ferdinand bereiste efteraaret Sverrig og Norge for der at søge afsads, og mine sønner giøre alt hvad der staaer i deres magt for at oprettholde en industrie, der giver flere tusinde brød, har bestaaet i aarhundreder og bragd ve!stand i vor egn. Ieg og mine have tillige denne handel vor velstand største delen at takke, ønsker derfor saa hjertelig, at mine sønners bestræbelser maatte bære frugter og handelen opretholdes; de ere io ogsaa for tiden fast de eneste som kand virke noget klækkelig til gavn for denne huusflidsfrembringelse.

Vores uldhandel var betydelig dette aar og der blev kiøbt circa $200.000 \mathbb{B}$, dog var fortienesten i forhold kuns ringe.

Ieg vovede dette aar at kiøbe en partie raps $1738 \mathrm{t}$., da sæden var saa sielden god, og det gik dermed Gud skee lov ret got, skiøndt [det] i førstningen saa ringe ud og prisen dalede.

1842 31/12. skarre $=$ skarve $=$ nedsætte prisen. 
Paa handelsubehageligheder manglede det ikke, dog kom ieg temmelig vel herfra, kand med rolighed see tilbage til det hele, og $i$ handelsverdenen vandt ieg end mere agtelse. Vel sielden gav det paa landet en handlende i vort land, der havde saa stoer, fast ubeskrænket kredit som ieg. Gid samme ogsaa for den kommende tid maatte opretholdes. - Mine børn vil vist giøre, hvad der staaer til dem, at dette skeer!

Ogsaa ubehagelighederne med min ældste broder endtes, og alt blev ordnet mellem os, hvorved ieg gav slip paa en deel af, hvad ieg med rette kunde fordre. Det var mig herom mindre at giøre end ieg vilde annerkiendelse af, hvad med rette kunde tilkomme mig, og ieg slet ikke kunde lide smaalig egennytte.

Skiondt vi havde en meget tor sommer, var aaret dog i det hele frugtbar, og det indhøstede var af sielden godhed. Kornpriserne vare ved aarets slutning: Rug $10 \mathrm{mk} .8 \mathrm{sk}$. à $11 \mathrm{mk}$., byg $6 \mathrm{mk}$. à $6 \mathrm{mk}$. 8 , havre $3 \mathrm{mk}$. $8 \mathrm{sk}$. à $4 \mathrm{mk}$. $8 \mathrm{sk}$., boghvede $9 \mathrm{mk}$. Hvede havde $\mathrm{i}$ forhold den laveste priis og kostede kuns 13 à $14 \mathrm{mk}$. tønden.

Quæghandelen var i det hele daarlig, og der blev mange penge tabt, dog holde denne egns kreature sig temmelig got $\mathbf{i}$ priis. Hæstene bleve kuns lidt søgde og daarlig betalte, sviin og faar vare ligeledes lættere i priis, flæsk 28 sk. à 2 mk. lpd., kiød 3 à $3^{1 / 2}$ sk. pd. ......

Stænderne vare forsamlede dette aar og min gamle broder var nok sidste gang i Viborg som stænderdepu[te]ret. - I Slesvig opvakte sprogforholdene ubehagelige debatter i stænderforsamlingen, hvortil den snavs P. H. Lorenzen fra Haderslev, der ville paa denne maade vise og udmærke sig, gav anledning. $\mathrm{Nu}$ fremstod der parthier, som traadte skarpe mod hinanden, det danske og det slesvig-holstenske. Forbittrelse opvaktes derved, dansk og tysk fiernede sig fra hinanden i høy grad og en sørgelig forbittrelse fremstod. Vakt var misnøye $\mathbf{i}$ forveien $\mathbf{i}$ hertugdcmmene ved indførelse af rigsbank skillemynt, som 
mand af alle kræfter satte sig imod, og misforstaaelsen blev storre ved de fatale sprogforhandlinger, saa tydske og danske bleve nu næsten fiendtlige mod hinanden, skiøndt de med hinanden Eyderne behersker. Kongen viste sig imidlertid saa betænksom som retfærdig, og haabentlig vil og god forstaaelse vende tilbage igien, hvilket saa meget er at ønske.

Min samtale med kongen den 17. aug. giør for mig ogsaa dette aar tænkelig, skiøndt det ikke førte til noget.

Ferdinand samtalte med vor milde dronning, der med naadig velbehag modtog de knipl., hun havde givet opdrag til at lade forfærdige til brug for kronprindsessen og bevidnede hendes tilfredshed derved, at hun lod Ferd. tilstille en kostbar brystnaal, der for mine børn og efterkommere afgiver et kiert tænkeminde.

\section{3.}

$18436 / 1 \ldots$ Brev fra broder Hans Wulff af sørgelig indhold, da sine børn truer med proces og protesterer imod overladelsen af sine eiendomme til Campen pukkende med, at der ey er bleven giort skifte efter moderen, og at han har kuns anbetroet gods, som ikke vilkaarlig kand forføyes over. Hvor smertelig dette for den gamle mand, Gud trøst ham stakkel, han er sandelig at beklage ....

$18438 / 1$... Vi have nu her i byen faaet vægter, der denne aften tiltraadte sin tieneste. Dette blev foranlediget ved Hierpsted præstegaards brand, der forrige uge brændte af, og hvor intet reddedes, creature og alt indebrændte.

$18439 / 1$... Skrev til past. Hansen i Hierpsted, en mand, som ieg ikke kiender, og vedlagde en anviisning paa Radoor stor $100 \mathrm{mk}$. som bidrag at erstatte hans stoere lidte tab ved ildebranden, fik nogle korte ord til svar fra ham igien...

1842 31/12. Eyderne: Læsningen usikker, formentl. menes ejderpolitikerne. 
$184312 / 1 \ldots$ Var den eftermiddag i Kummerleff, hvor Niels Hansens enkes land blev udleiet og temmelig got. Det beløb sig til 101 rdl., og 29 rdlr, er udleiet underhaanden, altsaa 130 rdlr.; forrige aar kuns 108 rdlr. Mand var saare glad ved min komme og hiertelig taknemmelig derfor, thi mand troer det gavner, naar ieg er tilstæde, birkfogden da bemøyer sig mere og er bedre stemt. Forrige aar var ieg der ikke. - Ieg har Gud skee lov den glæde gierne at være seet af bønderne, hvor ieg kommer og mand behandler mig overalt med udmærket agtelse....

$184320 / 1 \ldots$ Vor gode kiere naboe, den ærværdige pastor Lauterup fyldte i dag hans 80de aar og tilbragde som sædvanlig aftenen hos os. Dette vil sandsynlig være sidste gang, vi have denne glæde, thi alderen trykker ham og sligt fornøyer ham ikke mere.

$184328 / 1 \ldots$ Til Nebbel mølle, hvor ieg fandt alt i ængstlig spændt forventning over det forestaaende skiftemøde, hvilket ogsaa ængster mig.

$184330 / 1$ [Nebel mølle] ... Skiftemaalet fandt sted i dag, og min tilstædeværelse var til hæld for alle; det lykkedes mig at formilde den giensidige bittre stemmelse, at forsone og berolige; den vakre iustitsraad Oxenbøll giorde sit hertil, og 2de hidkaldte advokater fik Gud skee lov intet at bestille. Alt kom paa det rene, og alle fandt sig i billighed; alle gave afkald, og det hialp saa got, at ieg paatog mig at udbetale til Carl, Johansen og Toft de summer, som de skulle have. Campen er nu i besiddelsen, sikkert frielig med stoer giæld, men ieg haaber dog, at han vil kunde præstere. - Og saa bliver da den skiønne eiendom, som min broder i saa mange aar har virket for og saa at sige har skabt, i familiens hænder; Gud skee lov at alt er fredelig endt; og vil ieg ansee denne dag som en af mine lykkeligste. - Kuns den stakkels Carl beklager ieg. Han gik sin vey, da forrettningen var endt uden at tage afskeed med sin fader eller nogen, kunde ey forstaa sig til at forsone sig med sin fader, 
søster og svoger og forlod hans fødested med forbitret sind. Gid han maatte angre dette og udsone sig med alle igien. Gid han tillige bedre matte afbenytte hans tid som hidtil er skeet.

$18431 / 2$ [Nebel molle] ... Giorde formiddagen en lille tour i marken med Campen og blev temmelig vaad, - fornøyede mig over Campens forbedringer og hans planer. Det er en umsigtig og driftig landmand, der giøre alt muelige for at giøre sin mavre iord der frugtbringende. Og kand ieg kuns billige alle hans planer og foretagender, vist vil han bringe alt til større fuldkommenhed end min broder, og han har sandelig nok at virke paa. Hvad især fornøyer mig er den stoere mølledam, som bliver anlagd, hvilket vil være til megen gavn for møllen, ligesom det meget vil forskiønne Nebel mølles smukke omgivning. - Min gamle broder føler sig nu beroliget, saa lykkelig og tilfreds, har nu med verdenstummel og ubehageligheder intet mere at bestille, der saa got passer for hans høye alder, thi ogsaa hør- og stampemøllen samt kirketienden, der var forbeholdt $i$ kiøbecontracten, har han overladt Campen, der aarlig, saa længe min broder lever, heraf svarer $200 \mathrm{dlr}$. crt. -100 giver han frievillig desuden, og har min broder nu foruden frie vaaning $i$ hans smukke huus samt brænde circa 425 rdlr. crt. at leve af, der vil være fuldkommen tilstrækkelig at dække hans og hans datters udgivter....

$184313 / 2 \ldots$ Der var ringriden ved Bredebroe. Ferdinand med Eulalia og Dora vare med til dandsen ....

$184322 / 2 \ldots$ Vores gode Hochberg tiltraadte i dag hans reise til Tyskland; han agter [sig] til Berlin, Frankfurt a. d. O., Cassel, Frankfurt a. M. o. s. v. for at søge nye afsadskilder for vore knipl. ....

$184330 / 6$... Iuni bragde kuns liden varme, men især først i maaneden megen regn, der paa høye grunde var til gavn, men til stoer skade i det lave, især i mærsken, hvor stoere strækninger

1843 13/2. Eulalia = Hans Wulffs datter Marie Eulalia. 
bleve satte under vand, flere tusinde tønder sæd druknede, engene bedærvedes og mange kreature maatte opstaldes eller bringes op paa gesten til deels paa heden til stoer tab for det. fede quæg....

1843 22/8 [Før] ... Tog ved skiden vey til Dagebøll og til Wyck, hvor kongen, dronningen, kronprindsen og fast det hele hoff er, men fremmede badegiester ere her kuns faae....

1843 23/8 [Før] ... Kronprindsen tog bort herfra, afskeden ved indskibningen viste en god og hiertelig forstaaelse mellem fader og søn, skiøndt snak og rygte vil det modsatte. En interessant og ieg kand sige glædesdag var denne for mig. Ieg havde audience hos dronningen og hvilken blid modtagelse fandt ieg der. Hvor er dette dog en god siel, hvor fremlyser inderlig godhed og mildhed af alle hendes træk, af alle hendes yttringer, hvor vidner alt om, hvor inderlig hun ønsker at giøre alle hendes undersaatter lykkelige. Med megen roes omtalte hun de leverede kniplinger til kronprindsessen, der havde vunden alles biefald, ogsaa fra udlandet, hvem der havde seet varerne; lovede at biedrage til at fremme denne industrie og berørte, at da vi fik en russisk prindsesse her til landet, muligt en nye levering kunde finde sted. Hun forespurgte, hvor længe ieg havde ladet knipl. forfærdige og sagde da: „Ia! De har givet tusinde mennisker brød og giort Dem fortient for Deres fødeland."

Ieg var saa rørt ved denne nedladende godhed, at ieg ey var herre over mine fornemmelser, der gav sig luft ved taarer; ieg kunde kuns sige lidt, men de ord, ieg sagde, kom af mit inderste, og ieg troer det vandt hendes majestets biefald, thi da ieg gik bort og hendes vindver forbi, var hun traadt til vindvet, som ieg ikke bemærkede, men ieg hørte hendes blide englestemme raabe mig efter adieu, adieu! - vor samtale var dansk.

Hoffrøken Waltersdorf kom mig meget venlig imøde, berørte strax, at vi havde korresponderet sammen, takkede for min tilkiendegivne deeltagelse ved hendes kanefart for to vin- 
tre siden, hvor hun nær havde satt livet til, rakte mig haanden, da ieg tog afsked og var særdeles nedladende.

Skiøndt flere var for mig, der ønskede audience, saa var ieg dog den første, som blev indkaldt. - I forgemakket forefandt ieg grev Blücher, dronningens kammerherre, som var særdeles artig og underholdt sig rett fortrolig med mig, ligesom kammerherre Tillisch modtog mit besøg med udmærket godhed, og ieg kunde rett fortrolig meddele mig ham....

$184324 / 8$ [Før] . . . Havde denne eftermiddag audience hos kongen, fandt meget naadig modtagelse og underholdt mig temmelig længe med ham. Vore knipl. bleve omtalte, ogsaa han roeste de leverede for kronprindsessen og sagde: Naar De har saadant noget udmærket, da send det kuns ind, mand kand io alletider nok bruge det. Ieg berørte tillige det snevre spoors afskaffelse, samt hvor ønskelig det var, at den Langenhorner ledsætter formaaedes til at undervise een i sin kunst og andet mere.

Efter at have tagen afsked med kammerherrerne Tillisch og Krog, bemødte mig dronningen gandske simpel paaklædt; hun stod stille, tiltalte mig venlig, omtalte veyret og vi vexlede ikke saa faae ord sammen. S'aa havde ieg da endnu engang den glæde at see og tale denne i borgerlig stilling som med hensyn til moralsk værd saa høyt staaende person, og tanken heraf vil stedse glæde mig. Aldrig vil den milde fromme dronning svinde mig af minde, og hvor glæder ieg mig at have lært hende personlig kiende. Forlod endelig kl. 12 om natten Føhr.

$18435 / 9$. . [Husum] .. Natten storm, meget vindig dagen, dog blev det lidt efter lidt stillere. Kongen og dronningen kom over vandet med møye og besvær og ankom kl.1 til Munksbrück. Ved en af de 2de æresporte holdt Tønder amtmand en lille tale. Ieg stod nær vindvet af kareten, hvor kongen og dronningen sad.

1843 24/8. Snevre spoor o: hjulspor.

1843 5/9. Munksbrück = Munkebro kro i Okholm sogn, syd for Dageb $\varnothing 1$. 
Hun genkiendte mig og nikkede mig saa venlig til, og da vognen holdt til omspænd paa pladsen, blev ieg pludselig fremkaldt. Stræb! Kongen vil tale Dem, hedte det. Ieg traadte til vognen, hvor kongen sagde: Dronningen ønsker at see og tale Dem. Hun den naadige smilede mig saa mild og venlig imøde. Vi talte om overfarten, hvor dronningen sagdes at have været noget søsyg og ieg fortalte om min søn Ferdinand, der laae syg paa hospitalet i Christiania. Begge majesteters ansigtsudtryk viiste, at de toge hiertelig deel, og kongen trøstede mig med, at der var et særdeles got hospital i Christiania, hvor den syge ville finde den bedste pleie. ...

Et modstykke af venlighed mod mig var amtmanden i Tønder, der maaske ikke kunde lide denne nærmelse til majesteterne.

Ieg skrev paa en lille fortælling af mine audiencer til tidsfordriv og tog til Husum. Her var stoer støy, illumination, fakkeltog etc., da kongen tog af byen efter Heide for ved en natreise at indhente det forsømte, Dronningen var tagen til Nøer. - En lykke ieg ingen skye hæste havde, ellers var ieg kommen galt afsted; thi ieg kom ind midt i taaget. En utallig menneskehob med blussende fakler bemødte mig, hvor ieg længe maatte holde stille.

$184331 / 12 \ldots$. Atter et aar til ende og blot erindringen af samme tilbage. - Det var for mig og mine kiere en blanding af sorg og glæde, svære sygdomme hiemsøgde os, og tilstanden var en tiidlang sørgelig, men Herren hialp, opholdt alle, og vor glæde herover var stoer; ieg var den eneste, som blev forskaanet, alle øvrige, familie og tjenestefolk, vare meer eller mindre syge, Hochberg farligt, alle ovrige i forskiellig grad angreben. Ferdinand laae længe syg i Norge.

Hvad det oeconomiske angaar, da var kniplingshandelen daarlig. Hochberg giorde en forgieves reise til Tyskland og Holland og lom syg hiem. Ferdinand var i Norge, hvor han vist ville have udrettet mere, hvis han ey var bleven syg. 
Uldhandelen var ikke saa betydelig som forrige aar, dog blev der kiøbt $89255 \mathbb{H}$ mærskuld og $63232 \mathbb{H}$ iydsk, $2240 \mathbb{H}$ Brede-Ribe uld, ialt $154726 \mathbb{R}$. Raps kiøbte ieg $3595 \mathrm{tdr}$.

Min audience hos kongen og dronningen den 23. og 24. aug. giorde mig disse dage meget interessante og vil stedse blive mig i kiær erindring.

Høsten hvad rug angaar var god, sommerkornet derimod daarlig, især byg. Priserne vare ved aarets ende: Rug $7 \mathrm{mk}$, byg $6 \mathrm{mk}$. à $6 \mathrm{mk}$. $8 \mathrm{sk}$., havre $4 \mathrm{mk}$., boghvede $7 \mathrm{mk}$.

Quæghandelen var daarlig $i$ foraaret, men paa efteraaret blev det bedre, da fedtkvæg holdt sig i Hamb. got i priis. Her i byen som i omegnen er fast alt opkiøbt til græsning for næste aar og er bleven got betalt.

\section{4.}

$184410 / 4 \ldots$. . Vor gode Dora fik et frierbrev i gaar fra apotheker Nagel - og sandsynlig faar han ingen kurv. Hun besvarede venlig hans brev, dog uden at give bestemt løvte. Vist vil han glæde sig hendes brev, der er saa deilig skreven og fremstiller hende i sind og tanke, som hun er. Ia! han vil vist blive lykkelig med hende, i fald han ellers, som ieg haaber, fortiener det. - - -

$184419 / 4 \ldots$ Var med Theodor i Høyer for at erkyndige mig, især hos pastor Sønnichsen, hvordan omdømmet er over apoth. Nagels stilling og charakter, hvor i det hele berettningerne løde til hans fordeel; afgav til Nagel et brev fra min fromme gode Dora, hvormed hendes skiebne og stilling for den kommende tid blev afgiort. Maatte det gode barn blive lykkelig, saa lykkelig som hendes villie, sind og hierte fortiener det, og maatte hendes elsker stedse forstaa og skatte den lykke, der her vil vorde ham til deel, den er i sandhed stoer. Ia Gud velsigne det kiere gode barn og lad hendes fremtid vorde blid og lykkelig.

$184410 / 6 \ldots$ [Bredsted] ... Meget smukt veyr, der passede 
got for Bredsted friesefest, som blev holdt i dag, hvor flere tusinde mennesker fiern og nær indfandt dem, og hvor entrepreneuren Jessen, der havde kostbare foranstaltninger, kunde glæde sig ved dette vovestykke at være sluppen saa got. Ieg tog med Theodor didhen, og forefandt vi der ogsaa Ferdinand; der var music og sang, og mange taler bleve holdte, især af Tiedemann, der talte 4re gange, adv. Bremer og Besseler. - Ogsaa frieser holdte taler og i friesisk sprog, og mange toaster bleve udbragde. Det morede og interesserede mig i førstningen, men de alt for mange, til deels lange, taler, der især gik las paa at giøre de danske forhadte, mishagede og kiedede mig, og ieg forlod mylderen $\mathrm{kl} .4 \mathrm{og}$ tog til Mungsbrück. - - -

$184431 / 7 \ldots$. Stændernes sammentræden og den megen vrøvlerie med sprogsagen, især i Viborg gav tale- og skrivestoff nok, og disharmonien mellem danske og schlesw.-holstenere blev derved end mere forøget, ligesaa ved folkefæsterne i Bredsted; men især paa Skamlingsbakken opirredes gemytterne $\mathbf{i}$ høy grad. Der hersker disværre stoer forbitrelse, had og fiendskab mellem begge folkeslag, og var det som i gamle dage, da ville der være fremstaaet en blodig krieg; en stoer lykke for landet, at det har en saa viis og human konge, samt et ministerium, der fremtræder med fasthed; ellers kunde det have bleven broget nok $i$ vort land.

Det er de danske probagandister, der opirrer gemytterne ved tale og skrivt samt forsamlinger og vildleder den ukyndige, der ey forstaaer at skielne. Derfor er det ogsaa viis og klogt at slige forsamlinger er bleven forbudt ....

$184428 / 8$. . Der var i dag kirkevisitation. Ieg med Carl og Ferdinand vare med til gilden, og ieg fandt mig meget opmun-

1844 10/6. Tiedemann $\mathrm{b}$ : den slesvig-holstenske politiker, landinspektør Heinrich T. - Bremer o: slesv.-holst. politiker, advokat Jürgen B., Flensborg. - Besseler b: slesv.-holst. politiker, advokat Wilhelm Hartwig Beseler, Slesvig.

1844 31/7. Forbud mod forsamlinger, W. tænker formentlig på lukningen af den slesvigske forening 6/7 1844 . 
tret, mit beklemte sind lettet ved dette samliv. Amtmanden og provsten vare særdeles artige og venlige mod mig ...

$184430 / 8$. . V Vor 35 . bryllupsdag blev celebireret $i$ dag og giorde vore børn med tilstæde værende, blandt hvilke ogsaa Nagel og hans søster, alt muelige at forherlige samme, og salen tilbød aftenen et herlig skue, da vi bleve indførte i samme. ... En vrimmel af mennisker stode uden for vindverne sig gottende til det uvante syn. Efter aftensmaaltidet blev paa pladsen bengalisk fyr og andet fyrwærk given, der tog sig deilig ud, helst veyret saa meget begunstigede, thi det var en deilig aften. Tilsidst sang mand "Wie lieblich rinkt sie mir" til erindring af, at denne melodie blev spillet fra klokketaarnet i Andreasberg, da vi kom af kirken. Min gode kiere Wilhelmine var saa hierteglad ved alt, hvad hun hørte og saae, og alle glædte sig til vores glæde.

$18449 / 9$. . Ferd. med Carl, tante Grethe og Dora toge til Høyer, hvor kongen og dronningen ankom fra Føhr i dag, men de samt alle øvrige havde daarlig veyr og elendige veye. - -

$184411 / 9$... Kongen og dronningen kom til Closter i dag, men ingen af os vare der undtagen Carl, der kiørte med Mikkelsen. Toget gik i dag til Gram.

$184413 / 9$. . Hørte tillige efter Radoor, at majesteterne skal have forespurgt, hvor Brede var beliggende. Mand altsaa ikke har forglemt, men erindrer sig mig, hvilket ved min ubetydelighed er en stor udmærkelse og fortryder det mig meget, at ieg saa lidt i Høyer som Tønder og Closter har ladet mig see, hvilket var meget urigtig, uartig og stridende mod den taknemmelighed, ieg i saa høy grad skylder kongen og dronningen; men min kone og Hochberg var det saa meget imod, at ieg tog didhen, og saa lod ieg det beroe. ...

$184417 / 9 \ldots$. Vor gode kiere Dora fyldte i dag hendes 22de aar, og forlevede en glad dag. For at glæde os ved at glæde andre toge vi til fattighuuset, hvor vi drak kaffe med de fattige, ydede der forskiellige gaver. Ferdinand og Theodor spillede paa deres blæsende instrumenter; der blev dandset, og det 
var ret en glædesdag for de stakler, den gladeste de nuværende lemmer har havt og vil længe blive erindret af dem ...

$184422 / 9$. . Var eftermiddag i Harris . . og modtog her hilsen fra kongen og dronningen. Hans majestet havde i Ribe forespurgt hos Brasen, hvordan ieg levede og hvorledes det stod til hos mig, sagde derpaa: Hils Wulff fra dronningen. Hun interesserer sig meget for ham og havde ventet at see ham. - -

$184415 / 9$. . . Herredsfoged Brasen bragte $i$ gaar aften fra Ribe kommende det sørgelige budskab, at kongens cabinetssecretair, kammerherre Tillisch forgaars i Gram efter at have været paa jagd pludselig er død, rørt af et slag. - O! hvor giør det mig ondt, at kongen og landet berøves en mand, hvis villie var den bedste, hvis indflydelse var stoer, og der saa gierne fremmede alt, hvad got, ret og ædel var. Kongen taber meget, landet endnu mere, især hertugdømmene, hvis retfærdige talsmand han var ... Som amtmand i Apenrade stod han høyt anskreven hos mig og alle, men endnu mere vandt han, da han blev kongens raadgiver, og endnu mere gavnede han. Han blev sig selv alle tider liig, saa beskeden ligefrem. . . .

$184427 / 9$. . Pastor Lautrups datter Christiana, enke efter pastor Jessen, givtede sig i dag med tienestekarlen der, Lorens, Jens Ludvigs søn, et sær parthie, da hun er 50 aar, han 29. Hun har saa megen aand og dannelse, han saa liden og kontrasterer alt saa meget. Give Gud hun maae blive lykkelig ved det sære valg, og at denne dag alletider maatte blive hendes minde kier. - Skade, at hendes skiønne pension - circa $500 \mathrm{mk}$. aarlig nu falder bort, og vil det gielde, om hun og hendes mand kand leve af den lille gaard i Storde. Hun skrev nogle smukke linier til min kone, der bleve besvarede af hende og mig med en blomstervase med smukke blomster, som Hochberg mod aften bragte til Storde, der satte paa et bord, lagde brevet ved, og det unge par, især koenen, vil være bleven g:ade cverraskede ved saa

1844 27/9. Anne Christiane Lautrup ( digterinden Anna «) blev gift $2^{\circ}$ med Lorenz Ludvigsen. 
uventet at finde dette, der vidne om, at vi tage deel og ey svigte hende. Det gik meget stille af ved vielsen, kuns Lyd. Jacobsen som formynder og degnen med hans datter vare af fremmede tilstæde, og aftenen kl. 91/2 kiorte det nygivte par i ald stilhed til deres nye hiem.

Brev fra min gode gamle broder Hans efter hans hiemkomst fra Wiborg, hvor han paa en meget hædrende maade har tagen afsked fra stænderforsamlingen, hvis alderspræsident han fra første tid af var, og hvor han efter yderste kræfter har søgd at virke til gavn for sit fødeland....

$184430 / 9$... Kongens og dronningens reise til denne egn, deres bemøyelse at lære folkets politiske sindelag ved den forviklede sprogsag at kiende, den naade med hvilken begge erindrede mig, efterspurgte og lod hilse mig samt den brave gode Tillisch pludselige død i Gram fortienes ved maanedens slutning at bemærkes.

$184410 / 12 \ldots$. Var i dag i Tønder, hvor ieg ikke har været siden 15. iuli, altsaa i 5 maaneder og kommer der høyst ugierne, da paa Radoor nær alle de, ieg staar eller er i forbindelse med, ere saa usikre betalere... .

$184419 / 12$... Gustav Jacobsen tog hiem i dag; han har nu solgt sine 100 af pastor Lautrups portrait og vil trykke 50 endnu. Giør hermed en heldig handel og fortiener sig en artig lille sum, en glæde for vor gode præst her at varetage, hvor kier mand har ham....

$184431 / 12 \ldots$ Med hensyn til vor handelsvirksomhed, da havde vi mange vanskeligheder og ubehageligheder at kæmpe med, og fliden blev til dels lønnet med betydelig tab, havde maadelige udsigter for den kommende tid. Dog Gud skee lov for ikke værre, og at ieg har havd, samt afbenyttet en hældigere tid.

Uldhandelen, hvad mærskuld angaar, gik ringe og bragde ved den stærke koncurenz af franske kiøbere tab istæden for vinding. Det er mueligt ogsaa sidste aar, ieg befatter mig med 
denne handel. Med iydsk uld gik det derimod bedre, og er der haab til at denne handel kand fortsættes.

Raps kiøbte ieg ikke, endnu ligger de 550 t. fra forrige aar. Der kunde i may maaned være bleven got fortient herpaa, men [da] udsigterne vare saa ringe med dette aars høst, lod ieg mig besnakke til at lade den ligge, og vil der nu tabes i stæden for at vinde, hvilket kand være belærende for den kommende tid.

Med kniplingshandelen gik det ringe, og der er i denne handel en stærk tilbagegang. De mange gode konnezioner ieg havde i Tyskland som i America og andre verdensdele, vare disværre for det meste ey at afbenytte, da de eftergiorte fast overalt fortrænger de ægte kniplinger. Besynderlig nok, at den bedste afsadskilde for mine sønner var dette aar verdens modestad Paris. Til sin tid beskieftigede ieg næsten 1000 arbeiderinder, dette aar var antallet neppe 200. - I tabellen opgiven 3300 rbdlr., traad 230 rbdlr.

Bedre tegnede det sig med Ferdinand's fabrikanlæg af bomuldstøj væverie. 7 stoele vare igang og 12 mennisker herved beskieftiget. Værdien af det tilfærdigede var 2050 rbdlr., material 1100, og er der ald udsigt for, at denne industrie vil lade sig meer og mere udvide, hvorved mine sønner vil finde en dem tilsigende beskieftigelse, især dette Ferdinand.

Theodor bestemte sig for landvæsen, da han slet ingen tilbøyelighed har for handel og industrie. Vist vælger han det sikkerste og behageligste. Kuns havde ieg onsket, at han havde fulgt sin faders exempel og søgd at forene begge dele, hvilket mueligt ogsaa med tiden endnu kand skee.

En saare vigtig familiebegivenhed var vor gode fromme datters forlovelse med apotheker Hermann Nagel fra Høyer. Kuns er hermed det ubehagelige forbunden, at min søster eller egentlig hendes mand er i høy grad forbittret over, at valget ey faldt paa deres søn....

$184431 / 12$. Konnezioner $=$ konneksioner $=$ forbindelser. 
Med glæde erindrer ieg og min datter den reise, vi giorde til Tyskland dette efteraar. Det var mig saa kiert at varetage ey at være glemt af gamle venner og bekiendte, af iøder og christne, saa gierne at være seet igien og hos a 11 e at finde min gode villie anerkiendt, med taknemmelighed erindret, hvad ieg til deels længst havde glemt. Denne tour, disse erfaringer vil af mig aldrig vorde glemt, ligesom ogsaa min datter med interesse vil paatænke, hvad hun saae og hørte, hvilket vist altid i tanker vil glæde hende.

Aaret var iust ikke behagelig, sielden havde vi en varm dag, i foraaret tørke, siden regn, og høsten blev vanskelig, dog var samme i det hele temmelig tilfredsstillende, og det mangler Gud skee lov ikke paa føde enten for mennisker eller qvæg. Kornpriserne vare rug $6 \mathrm{mk}$. 8 à $7 \mathrm{mk}$., byg $5 \mathrm{mk}$. 8 à $6 \mathrm{mk}$., havre $3 \mathrm{mk} .8$ à $5 \mathrm{mk}$., boghvede , raps som var ringe groet og daarlig af qualitet, $15-18 \mathrm{mk}$. Kornhandelen ellers meget stille og kuns konsumtionkorn i betragtning.

Politisk vedvarer dette kevleri om tysk og dansk, hertil kommer spørgsmaalet om tronefølgen, og $i$ de forskiellige landets dele opstod end mere disharmonie. Vor gode konge med hans ministre ere sandelig at beklage. - Det er io en sand umuelighed at giøre alle det ret, er forstand og villie end nok saa $\operatorname{god} . .$.

[Efter at have omtalt russernes undertrykkelse af polakkerne fortsætter Wulff:]

O! hvor lykkelige ere vi i Danmark i sammenligning med forestaaende, hvor allene loven hersker, hvor der er saa megen sikkerhed for person og eiendom, og hvor mand ey allene har pligter, men ogsaa rettigheder, der mod kongen selv kand giøres gieldende, hvor mand uden ængstelig frygt tør udtale sig, og hvor saa meget skeer for at udbrede lys over alle forhold, og hvor ey attraaes at herske over slaver, men over et frie oplyst folk.

(Fortsættes).

1844 31/12. Boghvede: Prisen ikke angivet. 